\title{
The loricariid catfish genus Lasiancistrus (Siluriformes) with descriptions of two new species
}

\author{
Jonathan W. Armbruster
}

Lasiancistrus (Loricariidae: Hypostominae: Ancistrini) is diagnosed by the unique presence of a ventral strut of the pterotic and the presence of whiskerlike odontodes on the snout. Lasiancistrus has about 16 species assigned to it; however, only four are valid (L. schomburgkii, L. caucanus, L. guacharote, and L. heteracanthus), L. nationi is an Ancistrus, and L. trinitatus is incertae sedis in the Loricariidae. Lasiancistrus maracaiboensis and L. mystacinus are synonyms of L. guacharote; L. pictus, L. castelnaui, L. caquetae, L. guapore, L. multispinis, and L. scolymus are synonyms of L. schomburgkii; and L. planiceps, $L$. mayoloi, and $L$. volcanensis are synonyms of $L$. caucanus. Two new species are described: L. tentaculatus from the río Orinoco basin and L. saetiger from the rio Guama. The species can largely be told apart via color (L. schomburgkii has no or white spots on the fins, $L$. saetiger has entirely gray fins, and the rest have black spots in the fins), the presence of abdominal plates (L. caucanus, L. saetiger, and L. tentaculatus have naked abdomens, L. guacharote has a few small plates near the insertion of the pectoral fin, L. heteracanthus has a large patch of small plates, and L. schomburgkii is variable), and nuptial male condition (L. tentaculatus has small tentacles along the edge of the snout and the other species have a patch of whiskerlike odontodes at the corners of the snout). Most species are widespread in piedmont regions of South America with $L$. schomburgkii occurring in the Amazon, Orinoco, and Essequibo basins.

Lasiancistrus (Loricariidae: Hypostominae: Ancistrini) é diagnosticado pela presença do suporte ventral do pterótico e pelos odontódeos em forma de vibrissas no focinho. Lasiancistrus possui cerca de 16 espécies nominais, sendo que apenas quarto são reconhecidas como válidas (L. schomburgkii, L. caucanus, L. guacharote e L. heteracanthus), L. nationi é um Ancistrus, e L. trinitatus, incertae sedis dentro de Loricariidae. Lasiancistrus maracaiboensis e L. mystacinus são sinônimos de $L$. guacharote; L. pictus, L. castelnaui, L. caquetae, L. guapore, L. multispinis e L. scolymus são sinônimos de L. schomburgkii; e L. planiceps, L. mayoloi e L. volcanensis são sinônimos de L. caucanus. Duas novas espécies são descritas: L. tentaculatus da bacia do rio Orinoco e $L$. saetiger do rio Guama. As espécies podem ser claramente distinguidas pelo padrão de colorido ( $L$. schomburgkii não possui maculas brancas nas nadadeiras, L. saetiger possui nadadeiras completamente acinzentadas, enquanto as demais espécies possuem maculas negras nas nadadeiras), pelo padrão de placas abdominais (L. caucanus, L. saetiger e $L$. tentaculatus possuem abdomen nú, L. guacharote possui poucas placas próximas à inserção da nadadeira peitoral, $L$. heteracanthus possui um grande grupo de pequenas placas e L. schomburgkii é variável), e pela condição nupcial dos machos (L. tentaculatus possui pequenos tentáculos ao longo da borda do focinho e as demais espécies possuem um grupo de odontódeos semelhantes a vibrissas na margem do focinho). A maior parte das espécies encontra-se distribuída em regiões próximas à base da cordilheira na América do Sul, sendo que L. schomburgkii ocorre nas bacias Amazônica, do Orinoco e Essequibo.

Keywords: Ancistrini, Hypostominae, Systematics, Taxonomy.

\section{Introduction}

Lasiancistrus is a medium-sized genus (ca. 16 species recognized in Isbrücker, 2001 and Fisch-Muller, 2003) of the Loricariidae from the Amazon, Essequibo, Orinoco, Magdalena, San Juan, Atrato, Tuyra, and Bayano River drainages and the Lake Maracaibo drainage. Lasiancistrus was described by Regan (1904) as a subgenus of Ancistrus for those species of loricariids that have hairlike odontodes as part of the evertible cheek odontodes (later called whiskerlike odontodes; Armbruster 2004). The species included were Ancistrus heteracanthus Günther, 1869, A. pictus Castelnau, 1855, A. mystacinus Kner, 1854, and A. guacharote Valenciennes, 1840. The whiskerlike odontodes are unique among the Loricariidae (Armbruster, 2004). These odontodes are very narrow, but appear to be made out of the same material as the

Department of Biological Sciences, 331 Funchess, Auburn University, AL 36849, USA. 
rest of the odontodes (enamel and dentin). Later, Lasiancistrus was raised to genus level, and many unrelated species were placed into it (Isbrücker, 1980; Heitmans et al., 1983; Armbruster \& Provenzano, 2000). The genus was diagnosed by Armbruster $(1997,2004)$, and the taxonomy was greatly updated by Isbrücker (2001) and Fisch-Muller (2003).

The species recognized in Lasiancistrus by Isbrücker (1980) that were removed by Isbrücker (2001) were placed in several different genera. Hemiancistrus daguae Eigenmann, 1912 was recognized in Cordylancistrus, Ancistrus fuesslii Steindachner, 1911 and Pseudancistrus carnegiei Eigenmann, 1916 were recognized in Dolichancistrus, L. anthrax Armbruster \& Provenzano, 2000, L. dumus Armbruster \& Provenzano, 2000, L. nicoi Armbruster \& Provenzano, 2000, and L. tigris Armbruster \& Provenzano, 2000 were recognized in Pseudolithoxus Isbrücker \& Werner, 2001, Pseudancistrus genisetiger Fowler, 1941 and P. papariae Fowler, 1941 were moved to Lithoxancistrus, Hemiancistrus niger Norman, 1926, L. brevispinis Heitmans, Nijssen \& Isbrücker, 1983, and L. longispinis Heitmans, Nijssen \& Isbrücker, 1983 were moved to the new genus Guyanancistrus along with Chaetostomus schomburgkii Günther, 1864 (which is returned to Lasiancistrus below), and Ancistrus snethlageae Steindachner, 1911 was recognized in Ancistomus Isbrücker \& Seidel, 2001. Lithoxancistrus and Guyanancistrus were placed in the synonymy of Pseudancistrus by Armbruster (2004). Ancistomus was placed in the synonymy of Peckoltia by Fisch-Muller (2003) and Hemiancistrus by Armbruster (2004).

Several taxonomic problems are still inherent in Lasiancistrus due to the fact that most species were described from few, and in one case no, specimens, and localities are imprecise. An examination of the type specimens, the original descriptions, and a little detective work has led to this revision of the genus. Based on this study, four of the 16 described species are considered valid: L. heteracanthus (type of the genus), L. schomburgkii (Günther, 1864), L. caucanus Eigenmann, 1912, and L. guacharote. In addition, two new species are described (L. saetiger and L. tentaculatus). Lasiancistrus maracaiboensis Schultz, 1944, and L. mystacinus are synonyms of L. guacharote. Lasiancistrus castelnaui (Miranda Ribeiro, 1911) was originally published as a replacement name for $L$. pictus, which was preoccupied by Ancistrus pictus Kner, 1854 when both species were in Hemiancistrus (Miranda Ribeiro, 1911). Lasiancistrus castelnaui, L. caquetae (Fowler, 1945), L. guapore Knaack, 2000, L. multispinis Holly, 1929, L. pictus, and L. scolymus Nijssen \& Isbrücker, 1985, are synonyms of L. schomburgkii. Lasiancistrus planiceps Meek \& Hildebrand, 1913, L. mayoloi (Eigenmann, 1912), and L. volcanensis Dahl, 1942, are synonyms of L. caucanus. Chaetostomus trinitatus Günther, 1864, is occasionally recognized in Lasiancistrus, but there were no types designated for the species. The species cannot be placed to genus based on the original description and C. trinitatus is recognized as incertae sedis in the Loricariidae. In addition, Lasiancistrus nationi was found to be a species of Ancistrus. In this paper, Lasiancistrus and its species are described and diagnosed.

\section{Material and Methods}

Counts and measurements follow Armbruster (2003). In descriptions, modal numbers for counts are given unless no value occurred more than once. Museum acronyms follow Leviton et al. (1985). Number of whiskerlike odontodes included all thin odontodes on the cheek, excluding those on the opercle and snout. Species of Lasiancistrus do not vary much in terms of meristics and morphometrics; thus, most descriptive information for the species is in the genus description. The description of the species includes only those few characters that do vary among the species, counts that have wide ranges within Lasiancistrus, and color. The compound pterotic-supracleithrum-posttemporal is referred to simply as the pterotic. Tentacules are defined as odontode sheaths that are largely separated from the odontode posteriorly (Sabaj et al., 1999). Names for plate rows follow Schaefer (1997). The specimens listed as examined are only those measured, and number of specimens and standard lengths of those measured specimens are listed after the catalog numbers. Lots where no specimens were measured have the number of specimens listed as zero. In the case of paratypes of $L$. tentaculatus, the total number of specimens in the lot is listed and then the number of specimens measured is indicated in parentheses when the two values are not the same. Numbers following characteristics in the diagnosis of Lasiancistrus are character numbers and state numbers from Armbruster (2004). Specimens cleared and stained are listed as c\&s. Other abbreviations used are: $\mathrm{D}=$ distance, $\mathrm{Dia}=$ diameter, $\mathrm{L}=$ length, and $\mathrm{SL}=$ standard length.

\section{Lasiancistrus Regan, 1904}

Type Species. Chaetostomus heteracanthus Günther, 1869: 425, Figs. 3-4.

Diagnosis. Lasiancistrus is diagnosed by two unique synapomorphies from Armbruster (2004): presence of a posteriorly directed strut of the pterotic leading from the anterior process of the pterotic to the main body of the pterotic, which causes the dilatator operculi chamber to be open posteriorly (114: 1; Fig. 1; originally described by Schaefer, 1986) and presence of whiskerlike odontodes on the cheek (186: 1, Fig. 2). Lasiancistrus is also diagnosed by the following homoplastic synapomorphies: three branchiostegals (5:1), presence of a posteromedial invagination of the fifth ceratobranchial (11:1), presence of a ventral process on the quadrate for articulation with the canal plate (65:1), infraorbital six forming the entire ventral border of the orbit (89:1), loss of a deep pouch posteroventrally on the lateral ethmoid (98:0), loss of contact of the sphenotic and infraorbital six (117:1), and distal margin of rib of sixth vertebra flared distally so that the tip is much wider than the shaft (128:1). 


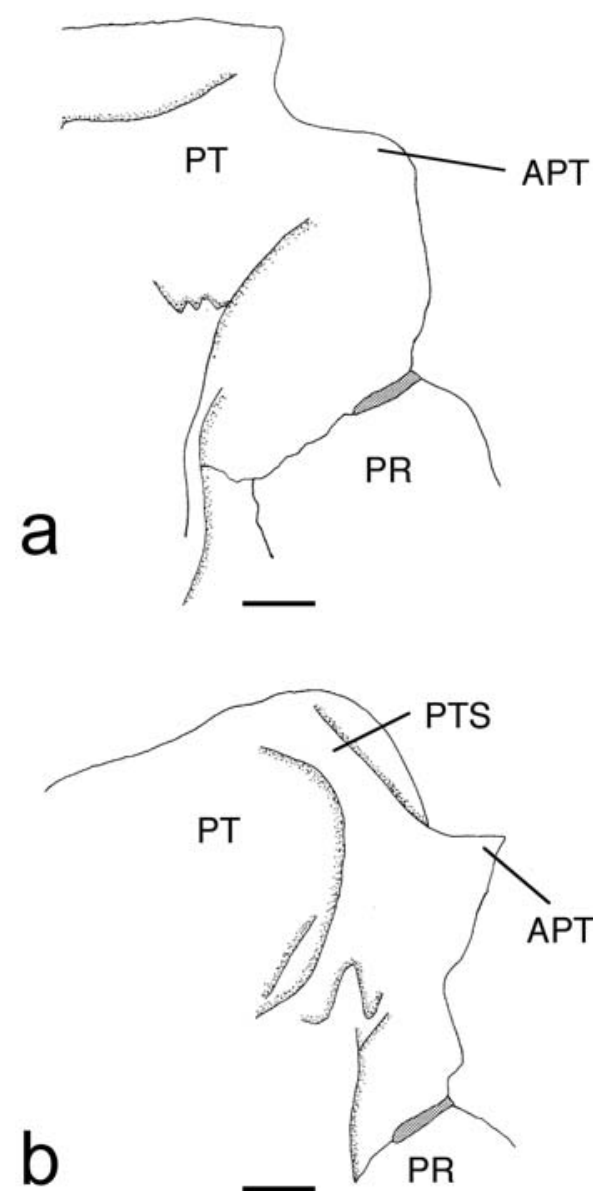

Fig. 1. Pterotic, right side, ventral view: a. Ancistrus pirareta, UMMZ 206085, b. Lasiancistrus guacharote, INHS 60465. Scale bars $=1 \mathrm{~mm}$. Shaded area is cartilage. APT $=$ anterior process of the pterotics, $\mathrm{PR}=$ prootic, $\mathrm{PT}=$ pterotics, and $\mathrm{PTS}=$ pterotics strut (forms over the open dilatator operculi chamber).

Adult Lasiancistrus can be separated from all other loricariids by the presence of whiskerlike odontodes on the cheek. In addition, Lasiancistrus can be separated from all other loricariids except members of the Pterygoplichthyini and Ancistrini by the presence of evertible cheek odontodes; from the Pterygoplichthyini by having three rows of plates on the caudal peduncle ( $v s$. five) and a modified, bar-shaped opercle (vs. a triangular opercle); from all except Ancistrus, Dekeyseria, Exastilithoxus, Lithoxus, Neblinichthys, and Pseudolithoxus of the Ancistrini by having three rows of plates on the caudal peduncle ( $v s$. five, rarely four); from all but Ancistrus by having nuptial males with tentacules on the pectoral-fin spines longer than their associated odontodes; from Ancistrus by having plates along the edge of the snout (vs. snout plates absent) and by maximally having transluscent tentacules on the snout that have odontodes associated with them ( $v s$. larger tentacles without associated odontodes colored the same as the head; even female and juvenile Ancistrus have some tentacles along the snout margin); from Dekeyseria by lacking keels on the lateral plates; from Exastilithoxus and Lithoxus by having greater than 30 teeth per jaw ramus (vs. less than 10) and by having oval lips (vs. round); from Neblinichthys by lacking hypertrophied odontodes on top of the head in nuptial males; and from Pseudolithoxus by lacking long, bristle-like odontodes on the leading edge of the pectoral-fin spine.

Description. Member of Ancistrini as diagnosed by Armbruster (2004). Medium-sized loricariids, largest specimen 190.4 mm SL. Body strongly dorsoventrally compressed and moderately wide. Head and nape gently sloped to insertion of dorsal fin. Dorsal profile very slightly sloped ventrally to dorsal procurrent caudal-fin spines, then rising slightly to caudal fin. Ventral profile flat to caudal fin. Supraorbital ridge almost absent with interorbital space slightly concave, almost flat. Supraorbital ridge continues as slightly higher, rounded ridge from anterior of orbit to slightly anteroventral of anterior nare. Mesethmoid raised slightly above lateral surface of snout to form slight ridge. Head contours smooth. Eyes small to medium.

Keels absent. All plates slightly convex medially to produce cylindrical body. Mid-dorsal and mid-ventral plate rows incomplete, generally ending below adipose fin; three rows of plates on caudal peduncle. Abdomen either naked, with
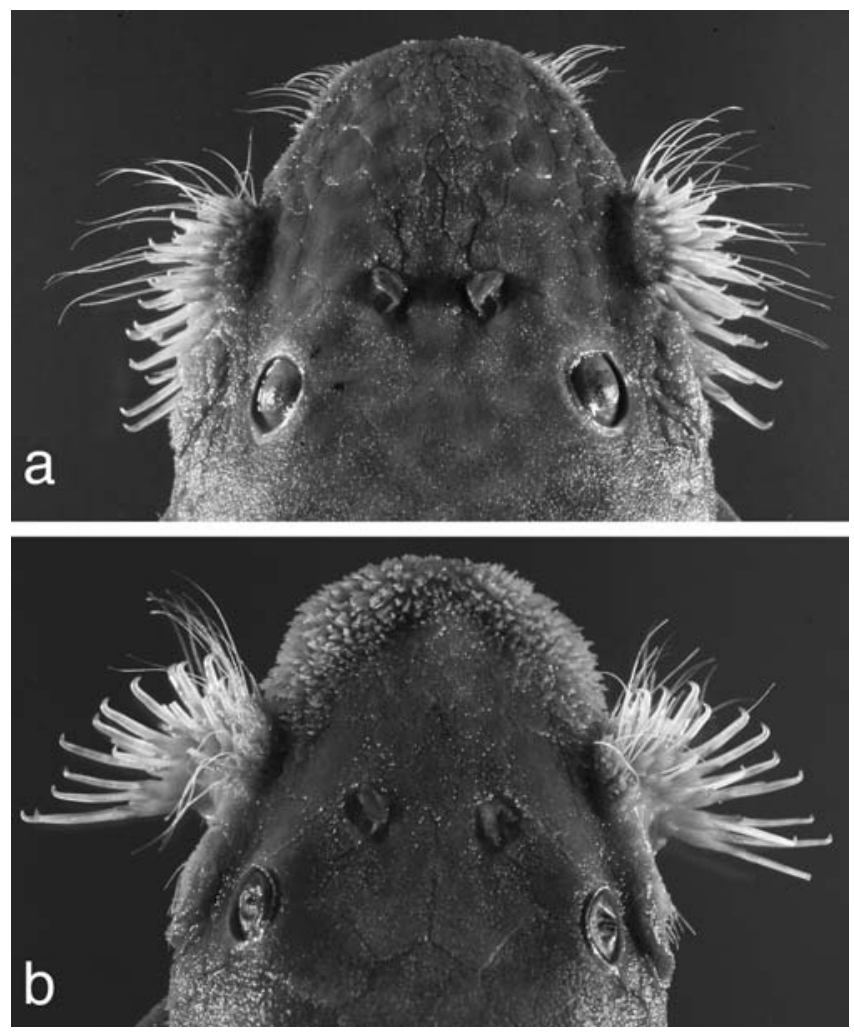

Fig. 2. Heads, dorsal view showing whiskerlike odontodes on cheek ( $\mathrm{a}$ and $\mathrm{b}$ ), whiskerlike odontodes on snout (a) and tentacules on snout (b) a. Lasiancistrus guacharote, ANSP 128695, $123.4 \mathrm{~mm}$ SL, b. Lasiancistrus tentaculatus, INHS 28650, $105.5 \mathrm{~mm}$ SL. 
few small plates near insertion of pectoral-fin spine, or with very small, embedded plates from pectoral girdle to anterior of pelvic girdle. First anal-fin pterygiophore not exposed to form platelike structure. 21-25 (mode $=24)$ plates in median series.

Frontals, infraorbitals, nasals, opercles, pterotics, sphenotics, and supraoccipital supporting odontodes. Opercular odontodes occasionally moderately hypertrophied, thick, and sharp; whiskerlike odontodes rarely present on opercle. Whiskerlike odontodes present in evertible cheek mass and occasionally at anterolateral corner of snout; 0-35 (mode $=13, \mathrm{~N}=152)$ whiskerlike odontodes in evertible cheek mass with number of whiskerlike odontodes increasing with size; $12-76($ mode $=25, \mathrm{~N}=159)$ total hypertrophied odontodes in cheek mass. Cheek plates evertible to approximately $90^{\circ}$ from head, hypertrophied cheek odontodes folded under opercle when relaxed. Odontodes on tip of pectoral-fin spine slightly hypertrophied. Odontodes on lateral plates not enlarged to form keels.

Dorsal fin not reaching preadipose plate when adpressed; dorsal-fin spine not elongate, edge of dorsal fin straight. Dorsal-fin spinelet V-shaped, dorsal-fin spine lock functional. Dorsal fin II,7 (one of 280 individuals II,6). Adipose fin with one preadipose plate and moderately long spine. Caudal fin slightly emarginate to forked, lower lobe longer than upper, $\mathrm{i}, 14, \mathrm{i}$ (one of 286 individuals i, 11,i, two i, 12,i, and four i, 13,i) with three to five (mode five, $\mathrm{N}=157$ ) dorsal procurrent caudal-fin rays and three to five (mode $4, \mathrm{~N}=157$ ) ventral procurrent caudal-fin rays. Anal fin short with unbranched ray weak and usually about three quarters length of first branched ray. Anal fin i,5 (one of 307 specimens i, 1, five i,4, and one i,6), Pectoral-fin spine reaching slightly posterior to inser-

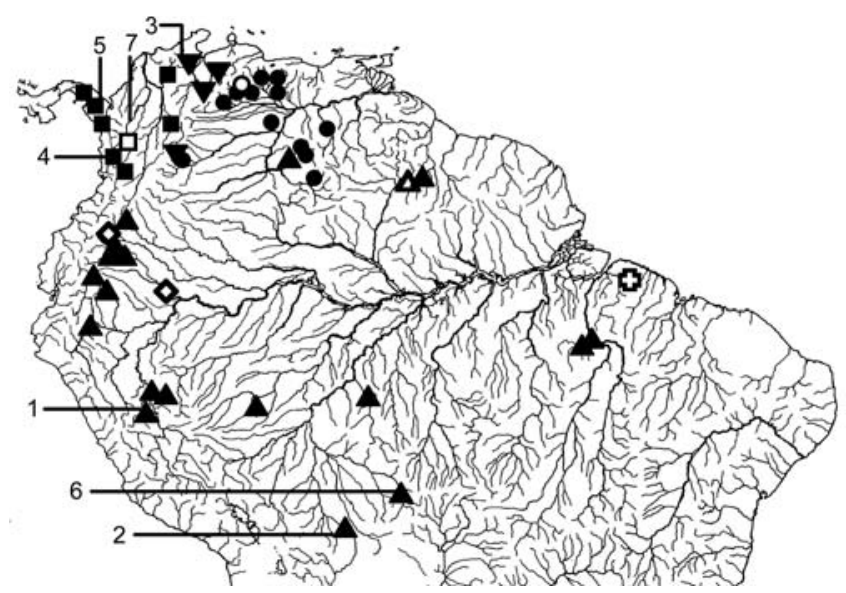

Fig. 3. Range of species of Lasiancistrus. Open symbols are type localities except for in $L$. heteracanthus where the type locality is not specific. Triangles $=L$. schomburgkii, squares $=L$. caucanus, upside down triangles $=L$. guacharote, diamonds $=L$. heteracanthus, cross $=L$. saetiger, and circles $=$ L. tentaculatus. The following are type localities for species in synonymy that have good locality information: $1 . L$. castelnaui (locality approximate), 2. L. guapore, 3. L. maracaiboensis, 4. L. mayoloi, 5. L. planiceps, 6. L. scolymus, 7. L. volcanensis. tion of pelvic fin when adpressed ventral to pelvic fin. Pectoral fin I,6 (three of 307 individuals I,5). Pelvic fin reaching to posterior of anal-fin when adpressed. Pelvic fin i,5 ( $\mathrm{N}=307)$.

Dorsal flap of iris present. Flap between anterior and posterior nares short. Lips wide, fairly thin. Upper lip with small, round papillae. Lower lip with medium-sized papillae anteriorly and smaller ones posteriorly. Maxillary barbels very short, not reaching behind lower lip, occasionally completely adnate. Buccal papilla small. Jaws moderately wide, dentaries forming very oblique angle; premaxillaries forming a very shallow arc with an overall angle just slightly less than $180^{\circ}$. Teeth with fairly long, narrow cusps; lateral cusp approximately half-length of medial cusp, stalks of teeth long; 39-101 dentary teeth (mode $=74, \mathrm{~N}=137)$ and $29-97$ premaxillary teeth $($ mode $=60, \mathrm{~N}=141)$.

Sexual dimorphism. Snout of nuptial males almost square ( $v s$. rounded in females and juveniles). Adult males of most species (except Lasiancistrus tentaculatus) with whiskerlike odontodes at anterolateral corner of snout (Fig. 2a); males of L. tentaculatus with tentacules instead of whiskerlike odontodes along anterior margin of snout (Fig. 2b). Nuptial males with tentacules longer than their associated odontodes on the pectoral-fin spine (Sabaj et al., 1999).

Range. Found throughout the Amazon River basin, the upper and middle of the Orinoco River basin, the Rupununi River basin (Essequibo River drainage), the Lake Maracaibo drainage, and drainages west of the Andes in Colombia and Panamá to the Bayano River (Fig. 3).

\section{Key to the Species of Lasiancistrus:}

1. Dorsal fin with either white spots in the dorsal fin or dorsal fin plain. Body typically with light spots or entirely dark

1'. Dorsal fin with black spots. Body with dark markings, light markings (if present) usually present as blotches or thick lines (except in río Bayano population in Panamá), body never completely dark

2. Body and fins with small white spots less than half the diameter of the plates (although spots may be faded). Plates entirely dark or with small spots ..... L. schomburgkii

2'. Body and paired fins with large white spots almost the same size as the plates, dorsal fin without spots. Plates outlined in black ................................................ L. saetiger

3'. Abdomen without plates ........................................................ 4

3. Abdomen with plates in at least a small patch medial to the insertion of the pectoral-fin spines ..................................... 5

4. Nuptial males with whiskerlike odontodes at the corners of the snout (Fig. 4, see also Fig. 2a). Caudal fin emarginate L. caucanus

4'. Nuptial males with tentacules along the anterior margin of the snout (Fig. 2b). Caudal fin forked ........... L. tentaculatus

5. Abdomen with plates underneath entire pectoral girdle and on abdomen ............................................ L. heteracanthus

5 '. Abdomen with only a couple of plates medial to insertion of pectoral-fin spines .................................. L. guacharote 
Lasiancistrus caucanus Eigenmann, 1912

Fig. 4

Lasiancistrus caucanus Eigenmann, 1912:11.Cartago, Colombia, C. H. Eigenmann, Jan-Mar 1912.

Hemiancistrus mayoloi Eigenmann, 1912:10. Río San Juan,
Ismina, Colombia, $5^{\circ} 11^{\prime} \mathrm{N}, 76^{\circ} 39^{\prime} \mathrm{W}$

Ancistrus planiceps Meek \& Hildebrand, 1913:79. Río Tuyra, Boca de Cupe, Panama.

Lasiancistrus volcanensis Dahl, 1942: 83. Río Volcán near its junction to río San Bartolomé, tributary of río Magdalena, Antioquia Dep., Colombia.

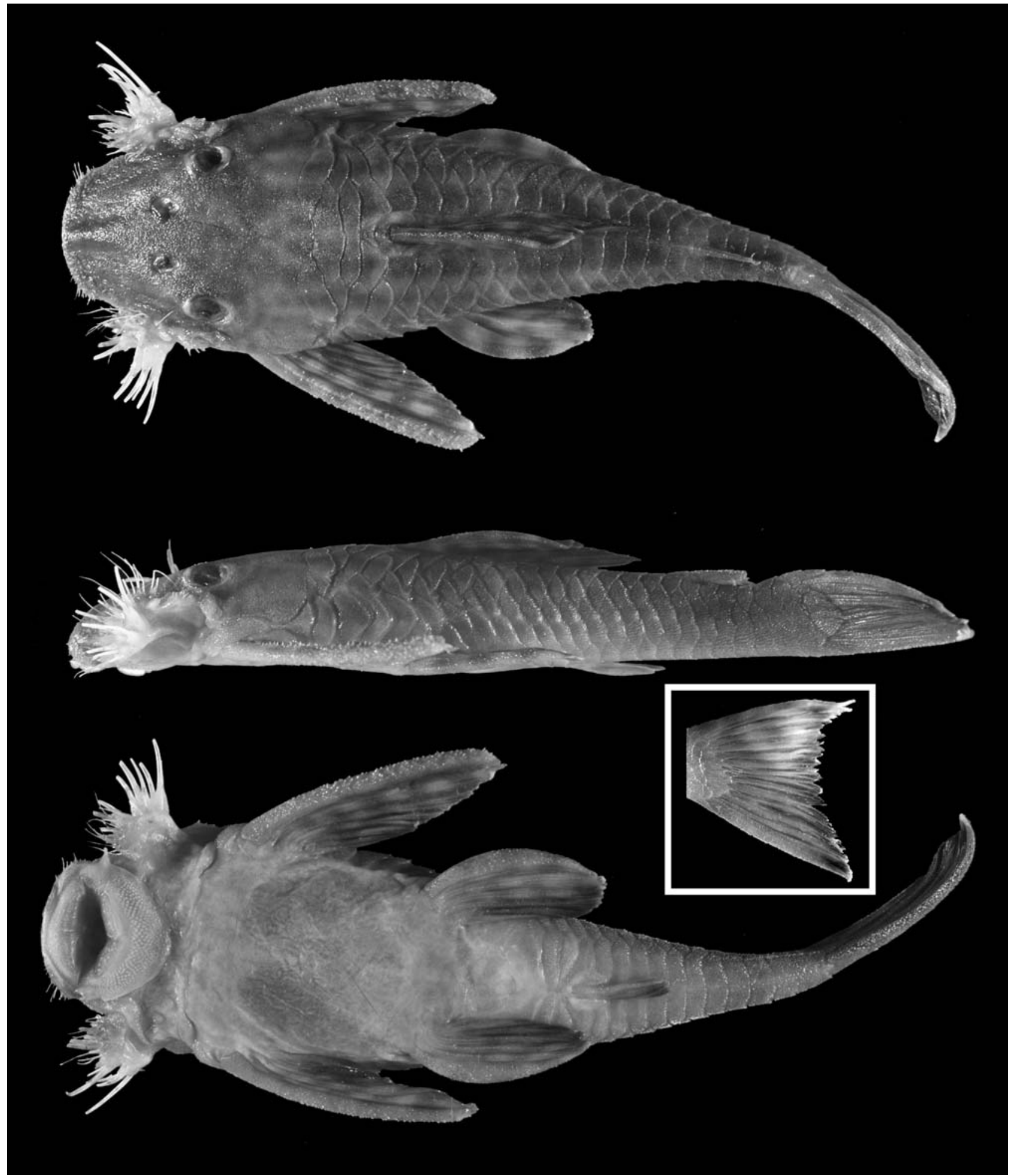

Fig. 4. Dorsal, lateral, and ventral views and inset of extended caudal fin of Lasiancistrus caucanus, SIUC 34914, 92.3 mm SL. 
Material Examined. Colombia. State not given: FMNH 56034, 1, $133.7 \mathrm{~mm}$ SL, holotype of L. caucanus, and FMNH 56035, 4, 77.9132.9 mm SL, paratypes of L. caucanus, Cartago, Jan-Mar 1912. FMNH 56037, 2, 62.5-85.7 mm SL, paratypes of L. mayoloi, Istmina, 18 Mar 1912. FMNH 58519, 1, 105.4 mm SL, Piedra Moler, 21 Feb 1912. FMNH 58560, 1, 54.3 mm SL, Paila, 1913. FMNH 58561, 0, Bernal Creek near Honda, 1913. FMNH 76219, 1, 79.7 mm SL, no locality. USNM 120723, 1, $57.6 \mathrm{~m} \mathrm{SL}$, río Ariguanicito tributary of río Cesar, 24 Mar 1942. USNM 308485, 1, 52.4 mm SL, río Salado, 4 miles above confluence with río Truando, 15 Mar 1967. USNM 175318, 2, 75.7-91.9 mm SL, Batatal, río Ure, San Jorge, 23 Dec 1950. Valle del Cauca, río Cauca - río Magdalena drainage: MCZ 35812, 1, $80.4 \mathrm{~mm}$ SL, upper río Cauca and tributaries, Oct 1942. MCZ 35871, 1, 44.5 mm SL, upper Cauca, río Frío, 18 Oct 1942. USNM 120155, 1, 73.5 mm SL, upper Cauca, río Frío, 18 Oct 1942. Caldas, río Cauca drainage: ANSP 134248, 7, 88.1-139.4 mm SL, río Mercedes, $1.5 \mathrm{hr}$ drive from Hacienda Sonadora, 23 Mar 1973. Choco: ANSP 88385, 4, 171.1$187.8 \mathrm{~mm}$ SL, upper río Jaredo, Pacific Slope, elevation $600 \mathrm{ft}$., Oct 1940. FMNH 56036, 1, 92.7 mm SL, holotype of L. mayoloi, upper río Jaredo, Pacific Slope, 18-20 Mar 1912. USNM 308484, 2, 35.4$41.0 \mathrm{~mm}$ SL, río Atrato drainage, small river (río Cuti?) near Santa Maria La Nueva, lower Atrato, 29 Aug 1967. USNM 308486. 2, 57.8$71.8 \mathrm{~mm}$ SL, creek of upper río Nercua, large tributary of río Truando, 28 Aug 1967. USNM 308487, 1, 1 c\&s, 99.0 mm SL, río Salado near Teresita, 8 Feb 1968. Santander, río Magdalena drainage: SIUC 34914, $92.3 \mathrm{~mm}$ SL, no precise locality given, Nov 1998. Panama. State not given: USNM 280395, 2, 96.2-119.9 mm SL, Atlantic Ocean drainage, Comarca Kuna Yala, río Cangandio Mandinga confluence area, $09^{\circ} 26^{\prime} \mathrm{N}$, 7905’W, 6-10 Feb 1986. USNM 308482, 1, 117.1 mm SL, río
Chucanaque, Pacific Ocean drainage, 0902'N, 7802'W, 1 Mar 1967. USNM 308492, 4, 137.1-187.9 mm SL, río Pirre, Pacific Ocean drainage, 3-5 miles above El Real, purchased (caught on line), 23-27 Feb 1967. Darien, Pacific Ocean drainage: FMNH 26290, 1, 190.4 mm SL, paratype of L. planiceps, río Tuyra, at mouth of río Yape, 6 Mar 1912. FMNH 26291, 1, 127.3 mm SL, paratype of L. planiceps, río Tuyra, Boca de Cupe, 26 Feb 1912. FMNH 26292, 1, 77.9 mm SL, paratype of L. planiceps, río Grande, Cana, 3 Mar 1912. FMNH 26293, 1, 82.5 mm SL, paratype of L. planiceps, río Cana, Cana, 1 Mar 1912. FMNH 29291, 1, $137.4 \mathrm{~mm}$ SL, paratype of L. planiceps, río Tuyra, Boca de Cupe, 28 Feb 1912. FMNH 29292, 1, 130.8 mm SL, paratype of $L$. planiceps, río Tuyra, Boca de Cupe, 28 Feb 1912. FMNH 29293, 1, $178.1 \mathrm{~mm}$ SL, paratype of L. planiceps, río Tuyra, Boca de Cupe, 28 Feb 1912. FMNH 7580, 1, 147.6 mm SL, holotype of L. planiceps, río Tuyra, Boca de Cupe, 26 Feb 1912. MCZ 88614, 2, 62.2-86.8 mm SL, río Pucuro, 3-4 km above confluence with río Tuira, $8^{\circ} 0^{\prime} \mathrm{N}, 77^{\circ} 31^{\prime} \mathrm{W}$, 17 Feb 1985. USNM 078309, 1, 43.9-101.7, río Grande, Cana, 3 Mar 1912. USNM 078311, 2, 121.2-177.1 mm SL, río Tuyra, mouth of río Yape, 6 Mar 1912. USNM 280394, 1, 125.3 mm SL, río Tuira, between Calle Larga and Pinogana above El Real, $08^{\circ} 07^{\prime} \mathrm{N}, 077^{\circ} 42^{\prime} \mathrm{W}, 18$ Feb 1985. USNM 293415, 4, 1 c\&s, 47.6-123.4 mm SL, río Pucuro just above confluence with río Tuira, $08^{\circ} 00^{\prime} \mathrm{N}, 077^{\circ} 32^{\prime} \mathrm{W}, 16-18 \mathrm{Feb}$ 1985. USNM 293418, 1, $138.0 \mathrm{~mm}$ SL, río Tuira, $0.5 \mathrm{~km}$ above Boca de Cupe, $08^{\circ} 03^{\prime} \mathrm{N}, 077^{\circ} 06^{\prime} \mathrm{W}, 18$ Feb 1985. Panama, río Bayano Pacific Ocean drainage: ANSP 151026, 9, 62.7-85.3 mm SL, río Canitas at IAH about $10.4 \mathrm{~km}$ W of Bayano bridge, 31 Jan 1983. MCZ 57075 , $1,84.6 \mathrm{~mm}$ SL, probably río Canita, on large rock ledge $0.5 \mathrm{~km}$ upriver of construction camp and headquarters, 1 Apr 1978. USNM 308490 , 3, 122.8-175.7 mm SL, río Membrillo, 22 Mar 1967.

Table 1. Selected morphometrics of Lasiancistrus caucanus and L. guacharote. Ratios are percent of SL (Predorsal L. to Pelvic-dorsal D.) or percent of Head L. (Head-eye L. to Premaxillary tooth cup L.).

\begin{tabular}{|c|c|c|c|c|c|c|c|c|c|}
\hline \multirow[b]{2}{*}{ Landmarks } & \multirow[b]{2}{*}{ Measurement } & \multicolumn{4}{|c|}{ L. caucanus } & \multicolumn{4}{|c|}{ L. guacharote } \\
\hline & & $\mathbf{N}$ & Mean & SD & Range & $\mathbf{N}$ & Mean & SD & Range \\
\hline $1-20$ & $\mathrm{SL}(\mathrm{mm})$ & 88 & 104.4 & 35.8 & $35.4-190.4$ & 40 & 75.7 & 15.9 & $42.2-119.5$ \\
\hline $1-10$ & Predorsal L. & 88 & 44.9 & 1.9 & $41.6-51.4$ & 40 & 45.5 & 2.0 & $41.9-51.6$ \\
\hline $1-7$ & Head L. & 88 & 36.4 & 1.8 & $33.0-41.2$ & 40 & 36.8 & 1.5 & $33.8-39.6$ \\
\hline $8-9$ & Cleithral W. & 88 & 30.0 & 2.2 & $25.6-37.0$ & 40 & 30.4 & 1.8 & $27.7-34.8$ \\
\hline $1-12$ & Head-pectoral L. & 88 & 28.1 & 1.6 & $24.8-33.5$ & 40 & 28.7 & 1.2 & $25.6-30.9$ \\
\hline $12-13$ & Thorax L. & 87 & 23.9 & 1.9 & $18.4-28.5$ & 40 & 23.7 & 1.8 & $19.1-27.8$ \\
\hline $12-29$ & Pectoral-spine L. & 86 & 33.7 & 3.4 & $25.9-41.3$ & 39 & 31.2 & 2.7 & $24.9-37.9$ \\
\hline $13-14$ & Abdominal L. & 88 & 22.5 & 1.3 & $19.6-26.6$ & 40 & 22.9 & 1.3 & $20.3-26.7$ \\
\hline $13-30$ & Pelvic-spine L. & 86 & 23.6 & 2.1 & $16.8-28.0$ & 40 & 25.5 & 1.1 & $22.1-27.3$ \\
\hline $14-15$ & Postanal L. & 87 & 32.5 & 2.3 & $25.9-37.2$ & 40 & 31.6 & 2.5 & $24.2-36.0$ \\
\hline $14-31$ & Anal-fin spine L. & 84 & 10.7 & 1.4 & $7.6-14.7$ & 40 & 11.2 & 1.2 & $7.8-14.3$ \\
\hline $10-12$ & Dorsal-pectoral D. & 88 & 27.7 & 1.4 & $24.1-31.7$ & 40 & 28.1 & 1.2 & $24.0-30.6$ \\
\hline $10-11$ & Dorsal spine L. & 80 & 26.6 & 2.4 & $21.3-31.1$ & 36 & 26.8 & 2.5 & $18.7-30.9$ \\
\hline $10-13$ & Dorsal-pelvic D. & 88 & 18.6 & 2.1 & $14.7-24.8$ & 40 & 18.5 & 1.7 & $14.8-23.1$ \\
\hline $10-16$ & Dorsal-fin base L. & 88 & 21.5 & 1.4 & $18.1-26.5$ & 40 & 21.6 & 1.3 & $19.9-26.2$ \\
\hline $16-17$ & Dorsal-adipose D. & 88 & 21.1 & 1.7 & $17.0-26.3$ & 40 & 20.0 & 2.0 & $14.0-23.3$ \\
\hline $17-18$ & Adipose-spine L. & 86 & 8.1 & 1.6 & $5.3-11.8$ & 39 & 9.3 & 1.4 & $6.9-12.5$ \\
\hline $17-19$ & Adipose-up. caudal D. & 88 & 13.5 & 1.8 & $8.6-17.9$ & 38 & 13.3 & 1.4 & $8.2-16.0$ \\
\hline $15-19$ & Caudal peduncle Dp. & 88 & 9.8 & 0.9 & $8.0-11.9$ & 40 & 10.2 & 0.8 & $8.4-12.3$ \\
\hline $15-17$ & Adipose-low. caudal D. & 87 & 18.5 & 1.7 & $14.2-23.5$ & 39 & 19.5 & 1.5 & $16.1-23.6$ \\
\hline $14-17$ & Adipose-anal D. & 87 & 19.6 & 1.6 & $14.2-22.5$ & 40 & 18.7 & 1.7 & $13.3-21.6$ \\
\hline $14-16$ & Dorsal-anal D. & 88 & 13.9 & 1.3 & $10.5-17.6$ & 40 & 15.2 & 1.4 & $12.6-19.2$ \\
\hline $13-16$ & Pelvic-dorsal D. & 86 & 22.1 & 2.0 & $13.9-26.7$ & 40 & 22.6 & 2.1 & $14.7-25.5$ \\
\hline $5-7$ & Head-eye L. & 87 & 41.8 & 1.9 & $35.2-46.6$ & 40 & 41.9 & 1.7 & $39.1-45.4$ \\
\hline $4-5$ & Orbit Dia. & 88 & 16.4 & 2.2 & $10.7-22.0$ & 40 & 17.2 & 1.7 & $14.7-20.9$ \\
\hline $1-4$ & Snout L. & 88 & 59.3 & 2.5 & $54.3-64.5$ & 39 & 61.8 & 1.8 & $57.4-65.1$ \\
\hline $2-3$ & Internares $\mathrm{W}$. & 87 & 14.3 & 1.3 & $10.9-19.4$ & 40 & 14.4 & 1.4 & $12.2-17.6$ \\
\hline $7-12$ & Head Dp. & 88 & 62.6 & 2.9 & $51.3-72.1$ & 39 & 62.5 & 3.5 & $51.2-68.5$ \\
\hline $1-24$ & Mouth L. & 88 & 43.5 & 3.5 & $32.1-51.5$ & 38 & 43.7 & 2.2 & $37.8-48.3$ \\
\hline $21-22$ & Mouth W. & 83 & 45.8 & 4.0 & $31.9-59.0$ & 39 & 49.8 & 5.1 & $40.3-63.4$ \\
\hline $22-23$ & Barbel L. & 86 & 4.5 & 1.9 & $1.2-10.9$ & 39 & 5.6 & 0.9 & $3.6-7.4$ \\
\hline $25-26$ & Dentary tooth cup L. & 88 & 15.2 & 2.8 & $10.1-23.9$ & 40 & 17.4 & 3.7 & $13.0-28.7$ \\
\hline $27-28$ & Premaxillary tooth cup L. & 88 & 14.8 & 2.5 & $9.3-23.7$ & 40 & 16.4 & 2.3 & $13.2-22.8$ \\
\hline
\end{tabular}


Diagnosis. Lasiancistrus caucanus is distinguished from all other species of Lasiancistrus except $L$. saetiger, L. tentaculatus, and some L. schomburgkii by the absence of plates ventrally in front of the anus and from all Lasiancistrus except some $L$. guacharote by having the caudal fin slightly emarginate (vs. forked; Fig. 4). Additionally, L. caucanus can be separated from $L$. schomburgkii and $L$. saetiger by having dark spots in the dorsal fin ( $v s$. dorsal fin all gray or with white spots); from L. tentaculatus by having tentacules along the snout that are shorter than their associated odontodes in nuptial males (vs. longer in nuptial males), and by having whiskerlike odontodes at the anterior corner of the snout in nuptial males ( $v s$. whiskerlike odontodes absent, Fig. 2a).

Description. See genus description for more information. Morphometrics in Table 1. Largest specimen $190.4 \mathrm{~mm}$ SL. Abdomen naked. 21-25 (mode $=24)$ plates in median series. 435 whiskerlike odontodes in evertible cheek mass (mode $=11$, $\mathrm{N}=49) ; 21-76($ mode $=39, \mathrm{~N}=57)$ total hypertrophied odontodes in cheek mass.

Color. Color variable. Body typically light brown with dark, wavy stripes that may break up into dashes or spots posteriorly. Light areas occasionally exist as spots rather than background color. Head mottled or with light spots. Body and head sometimes uniformly dark. Abdomen uniformly light tan, lower surface of caudal peduncle darker than abdomen. Dorsal fin with large, rectangular spots centered and darkest on fin rays, almost combing to form bands. Paired, caudal, and anal fins with narrow bands. Lower half of caudal fin slightly darker than upper. Adipose fin uniformly dark. Color darkens with size.

Sexual dimorphism. Nuptial males with whiskerlike odontodes at the anterolateral corner of the snout, else as in genus description.

Range. Lasiancistrus caucanus has a trans-Andean distribution in the ríos Magdalena, Atrato, San Juan, Tuyra, and Bayano drainages of Colombia and Panamá (Fig. 3).

Comments: Lasiancistrus caucanus and L. mayoloi were both described by Eigenmann (1912); however, L. mayoloi was described in Hemiancistrus. Because L. caucanus was described in the correct genus and $L$. mayolo $i$ was not, $L$. caucanus was chosen as the valid name for the species. The type of Lasiancistrus volcanensis was not examined; however, no significant differences could be found in any of specimens examined from west of Lago Maracaibo. The figures in Dahl (1942) appear identical to all other specimens collected in the region, so $L$. volcanensis is listed as a synonym of $L$. caucanus.

Most specimens available have the colors faded, but those that do have color left show little variation across the transAndean region they occupy and no other characteristics could be found to support any of the species listed above as synonyms. The only difference in color pattern is from specimens collected from the río Bayano, the furthest west river in the range of $L$. caucanus in Panamá. These specimens have the light areas of the body as spots instead of forming a light background; however, the other elements of the color pattern are as in the rest of the species. Few specimens are available from the Bayano to make comparisons, so it is unknown if this population would require separate species status.

\section{Lasiancistrus guacharote (Valenciennes, 1840)}

Fig. 5

Hypostomus guacharote Valenciennes, in Cuvier \& Valenciennes, 1840: 508. Puerto Rico [locality in error, see comments].

Ancistrus mystacinus Kner, 1854: 276. Caracas, Venezuela [1ocality in error, see comments].

Lasiancistrus maracaiboensis Schultz, 1944: 314. Río Socuy, $3 \mathrm{~km}$ above its mouth, Venezuela.

Material Examined. Venezuela. Zulia, lago Maracaibo drainage: AUM 22136, 1, $80.1 \mathrm{~mm}$ SL, caño El Padre (tributary of río Onia río Escalante) on road from Hwy 2 to town of $\mathrm{KM} 35,8.76161^{\circ} \mathrm{N}$, $071.76314^{\circ} \mathrm{W}, 19 \mathrm{Dec} 1999$. INHS 60465, 2 c\&s, río Yasa, río Palmar basin, $5 \mathrm{~km}$ S Machiques on road to Tucoco, 9 Jan 1991. MNHN A9567, 1, $84.7 \mathrm{~mm}$ SL, holotype of L. guacharote, locality given as Porto Rico, but most likely from the lago Maracaibo basin of Venezuela, see comments. NMW 44200, 1, $65.6 \mathrm{~mm}$ SL, holotype of $L$. mystacinus, locality given as Caracas, but this is likely a mistake, see comments. UF 30724, 3, 42.2-69.0 mm SL, río Palmar on Route 6 (Maracaibo-Machiques road) at Hacienda Mucuras, 14 Mar 1981. UF 30744, 3, 55.9--65.1 mm SL, río Araquaisa at Route 6 bridge (Machiques-La Fria), 14 Mar 1981. USNM 121038, 1, 119.5 mm SL, holotype of $L$. maracaiboensis, río Socuy $3 \mathrm{~km}$ above mouth, 24 Feb 1942. USNM 121048, 2, 26.6-90.7 mm SL, paratypes of $L$. maracaiboensis, río Motatan 4 km above Motatan, 25 Mar 1942. USNM 121050, 2, 23.3-89.5 mm SL, paratypes of L. maracaiboensis, río San Pedro tributary of río Motatan) at bridge, 20 Mar 1942. USNM 121049, 7, 64.5-107.4 mm SL, paratypes of $L$. maracaiboensis, río Socuy $3 \mathrm{~km}$ above mouth, 24 Mar 1942. Merida, lago Maracaibo drainage: INHS 59866, 4 c\&s, río Escalante at highway 1 bridge, 7 Jan 1991. UF 30779, 12, 67.9-89.0 mm SL, río Chama just N of El Vigia on the road to Merida, 15 Mar 1981. Tachira, lago Maracaibo drainage: UF 30768, 6, 55.8-68.0 mm SL, río Orope at bridge between La Fria and La Honda, at km marker 817, 15 Mar 1981. UF 25472, 3, 57.4-81.1 mm SL, Municipality Alberto Adriani, 25 May 1977. Colombia, Meta, ANSP 128695, 0, río Orinoco drainage (probably introduced, see Comments): río Negro just downstream from main Villavicencio-Puerto Lopez highway at La Balsa, E side of river, 44’ N, 73²'W, 3 Jan 1972.

Diagnosis. Lasiancistrus guacharote can be separated from all other species of Lasiancistrus except for some $L$. schomburgkii by having a single to a small patch of platelets ventromedially from the insertion of the pectoral-fin spine (Fig. 5) and nowhere else ventrally, and from $L$. schomburgkii by 


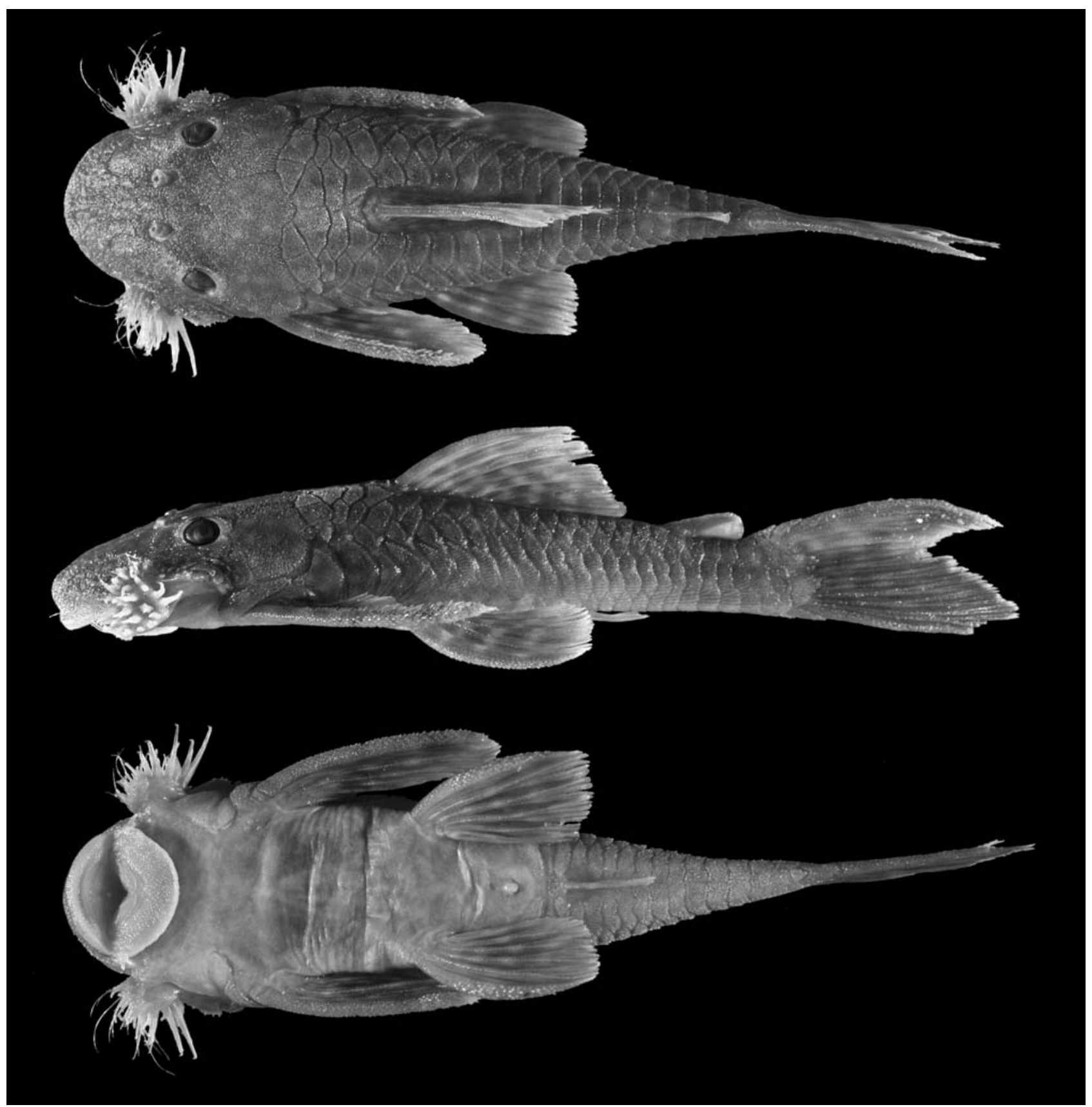

Fig. 5. Dorsal, lateral, and ventral views of Lasiancistrus guacharote, AUM 22136, $80.1 \mathrm{~mm}$ SL.

having black spots in the dorsal fin (vs. no or white spots) and black bands in the paired and caudal fins ( $v s$. bands absent).

Description. See genus description for more information. Morphometrics in Table 1. Largest specimen $119.5 \mathrm{~mm}$ SL. Abdomen naked. 23-25 (mode $=24)$ plates in median series. 424 whiskerlike odontodes in evertible cheek mass $(\operatorname{mode}=16$, $\mathrm{N}=26$ ); $17-43$ (mode $=25, \mathrm{~N}=26)$ total hypertrophied odontodes in cheek mass.

Color. Small, white spots on head, fading on nape. Body mottled with faint hint of dorsal saddles. Abdomen light tan, ventral surface of caudal peduncle slightly darker. Dorsal fin with large, rectangular spots centered and darkest on fin rays, almost combing to form bands. Paired, caudal, and anal fins with narrow bands. Lower half of caudal fin slightly darker than upper. Adipose fin uniformly dark. Color darkens with size.

Sexual dimorphism. Nuptial males with whiskerlike odontodes at the anterolateral corner of the snout, else as in genus description.

Range. The Lago Maracaibo basin of Venezuela and Colombia (Fig. 3). 
Table 2. Selected morphometrics of Lasiancistrus heteracanthus and L. saetiger. Ratios are percent of SL (Predorsal L. to Pelvic-dorsal D.) or percent of Head L. (Head-eye L. to Premaxillary tooth cup L.).

\begin{tabular}{|c|c|c|c|c|c|c|c|c|c|}
\hline \multirow[b]{2}{*}{ Landmarks } & \multirow[b]{2}{*}{ Measurement } & \multicolumn{4}{|c|}{ L. heteracanthus } & \multicolumn{4}{|c|}{ L. saetiger } \\
\hline & & $\mathbf{N}$ & Mean & SD & Range & $\mathbf{N}$ & Mean & SD & Range \\
\hline $1-20$ & $\mathrm{SL}(\mathrm{mm})$ & 3 & 107.9 & 41.5 & $66.2-149.2$ & 4 & 88.4 & 9.7 & $77.2-100.1$ \\
\hline $1-10$ & Predorsal L. & 3 & 44.8 & 2.0 & $43.0-46.9$ & 4 & 45.9 & 0.8 & $45.0-46.7$ \\
\hline $1-7$ & Head L. & 3 & 36.3 & 3.1 & $33.8-39.8$ & 4 & 38.2 & 2.1 & $36.4-41.3$ \\
\hline $8-9$ & Cleithral W. & 3 & 29.5 & 2.2 & $27.6-31.8$ & 4 & 32.5 & 0.9 & $31.2-33.1$ \\
\hline $1-12$ & Head-pectoral L. & 3 & 29.3 & 3.1 & $26.4-32.5$ & 4 & 28.7 & 1.6 & $27.4-30.9$ \\
\hline $12-13$ & Thorax L. & 3 & 23.0 & 1.4 & $21.4-23.9$ & 4 & 22.6 & 0.7 & $22.0-23.6$ \\
\hline $12-29$ & Pectoral-spine L. & 3 & 32.4 & 5.8 & $28.4-39.1$ & 4 & 35.7 & 0.5 & $35.0-36.1$ \\
\hline $13-14$ & Abdominal L. & 3 & 22.1 & 1.5 & $20.5-23.4$ & 4 & 23.2 & 1.1 & $21.8-24.2$ \\
\hline $13-30$ & Pelvic-spine L. & 3 & 24.2 & 2.3 & $22.4-26.8$ & 4 & 23.1 & 0.7 & $22.3-24.0$ \\
\hline $14-15$ & Postanal L. & 3 & 33.7 & 0.7 & $32.8-34.2$ & 4 & 33.8 & 0.3 & $33.3-34.1$ \\
\hline $14-31$ & Anal-fin spine L. & 3 & 10.1 & 3.1 & $8.2-13.7$ & 4 & 10.5 & 0.9 & $9.4-11.4$ \\
\hline $10-12$ & Dorsal-pectoral D. & 3 & 27.1 & 0.7 & $26.4-27.8$ & 4 & 27.5 & 0.6 & $26.6-28.1$ \\
\hline $10-11$ & Dorsal spine L. & 3 & 28 & 2.1 & $25.9-30.1$ & 4 & 22.9 & 3.2 & $18.3-25.4$ \\
\hline $10-13$ & Dorsal-pelvic D. & 3 & 18.3 & 1.3 & $17.3-19.7$ & 4 & 18.9 & 1.7 & $16.7-20.8$ \\
\hline $10-16$ & Dorsal-fin base L. & 3 & 21.6 & 1.1 & $20.5-22.7$ & 4 & 22.8 & 0.4 & $22.2-23.3$ \\
\hline $16-17$ & Dorsal-adipose D. & 3 & 20.6 & 0.7 & $19.8-21.2$ & 4 & 20.3 & 1.2 & $18.9-21.9$ \\
\hline $17-18$ & Adipose-spine L. & 3 & 6.1 & 1.0 & $4.9-6.9$ & 4 & 8.3 & 0.6 & $7.6-9.0$ \\
\hline $17-19$ & Adipose-up. caudal D. & 3 & 13.3 & 0.6 & $12.9-14.0$ & 4 & 14.2 & 0.7 & $13.4-14.8$ \\
\hline $15-19$ & Caudal peduncle Dp. & 3 & 9.6 & 1.8 & $7.7-11.3$ & 4 & 10.4 & 0.3 & $10.1-10.8$ \\
\hline $15-17$ & Adipose-low. caudal D. & 3 & 18.8 & 0.9 & $17.8-19.5$ & 4 & 19.5 & 0.4 & $19.2-20.0$ \\
\hline $14-17$ & Adipose-anal D. & 3 & 20.3 & 0.4 & $19.9-20.7$ & 4 & 20.2 & 0.5 & $19.8-21.0$ \\
\hline $14-16$ & Dorsal-anal D. & 3 & 13.2 & 2.2 & $10.7-14.7$ & 4 & 12.9 & 0.6 & $12.2-13.7$ \\
\hline $13-16$ & Pelvic-dorsal D. & 3 & 22.8 & 0.8 & $21.9-23.3$ & 4 & 23.9 & 0.9 & $23.1-25.1$ \\
\hline $5-7$ & Head-eye L. & 3 & 41.6 & 1.7 & $40.1-43.5$ & 4 & 37.6 & 3.1 & $33.4-40.6$ \\
\hline $4-5$ & Orbit Dia. & 3 & 15.8 & 2.4 & $13.3-18.1$ & 4 & 17.2 & 1.4 & $15.1-18.5$ \\
\hline $1-4$ & Snout L. & 3 & 63.5 & 1.2 & $62.6-64.4$ & 4 & 66.2 & 3.4 & $61.2-68.9$ \\
\hline $2-3$ & Internares $\mathrm{W}$. & 3 & 15.6 & 1.5 & $14.5-16.7$ & 4 & 15.8 & 1.0 & $14.3-16.5$ \\
\hline $7-12$ & Head Dp. & 3 & 61.4 & 1.1 & $60.4-62.6$ & 4 & 61.1 & 3.4 & $57.0-65.0$ \\
\hline $1-24$ & Mouth L. & 3 & 42.2 & 4.0 & $38.9-46.6$ & 4 & 45.6 & 2.8 & $42.0-47.9$ \\
\hline $21-22$ & Mouth W. & 3 & 47.7 & 3.4 & $43.9-50.4$ & 4 & 52.3 & 4.2 & $46.9-56.4$ \\
\hline $22-23$ & Barbel L. & 3 & 4.2 & 2.0 & $2.3-6.3$ & 4 & 3.9 & 0.4 & $3.5-4.2$ \\
\hline $25-26$ & Dentary tooth cup L. & 3 & 13.2 & 0.4 & $12.7-13.5$ & 4 & 16.0 & 0.4 & $15.5-16.4$ \\
\hline $27-28$ & Premaxillary tooth cup L. & 3 & 14.2 & 0.6 & $13.5-14.8$ & 4 & 17.8 & 1.6 & $15.4-18.9$ \\
\hline
\end{tabular}

Comments: The holotype of Lasiancistrus guacharote is said to be from Puerto Rico (Cuvier \& Valenciennes, 1840), but it is highly unlikely that loricariids could have arrived naturally on this northern Caribbean island. The holotype was collected by Augus Plée, a young adventurer-naturalist who collected fish specimens from around the Caribbean and the Gulf of Mexico in the 1820's, and who did collect in Puerto Rico (Pietsch, 1995). Plée also collected in the Maracaibo basin of Venezuela. Specimens of upland fishes that are known to be sympatric with Lasiancistrus such as Parodon Valenciennes, 1850 and Piabucina Valenciennes, 1850 were collected by Plée in the Maracaibo basin according to the MNHN catalog on the internet. Examination of the type reveals that it has the characteristic used to diagnose the species from the Maracaibo Basin. In all likelihood, the locality was somehow misplaced. Plée was not around to correct the error because he died on the day he was to return to France (Pietsch, 1995).

Lasiancistrus mystacinus was described by Kner (1854) based on a single specimen with the stated locality of "Caracas". The drainage in Caracas is the río Tuy, and no Lasiancistrus have been reported from the Tuy. It is believed that the locality "Caracas" in Kner's work simply means where the specimens left Venezuela (R. P. Vari, pers. comm.), and that these specimens could have come from anywhere in Ven- ezuela. The type of L. mystacinus has the plates only in the corners of the pectoral girdle as is used to diagnose $L$. guacharote and is considered a synonym. The only other species of Lasiancistrus in Venezuela is L. tentaculatus, which lacks plates on the abdomen and L. schomburgkii, which has more plates on the abdomen.

Lastly, Schultz (1944) described Lasiancistrus maracaiboensis as the first species of Lasiancistrus in Venezuela with an accurate type locality. These specimens also have a small patch of platelets near the insertion of the pectoral-fin spine. Kner (1854) and Schultz (1944) both mention the resemblance of L. mystacinus and L. maracaiboensis, respectively, to L. guacharote, and suggest that because of the poor description, the identity of $L$. guacharote was uncertain and that a new species should be described. Schultz (1944) was further restricted from viewing the types of $L$. guacharote and L. mystacinus by the events of World War II.

Lasiancistrus guacharote occurs in one river in the río Meta - río Orinoco drainage of Colombia. These specimens are clearly $L$. guacharote as they have a patch of platelets ventrally near the insertion of the pectoral-fin spines, whiskerlike odontodes at the edge of the snout, and dark spots in the dorsal and caudal fins. Two other species are known from the río Orinoco, drainage: L. schomburgkii and 
L. tentaculatus. Lasiancistrus schomburgkii has white spots in the dorsal and caudal fins (vs. having dark spots in the fins), and L. tentaculatus has no abdominal plates and has tentacules along the snout instead of whiskerlike odontodes. The collection of these fishes (ANSP 128695) is from around Villavicencio, a town well connected with the aquarium export business. It is likely that the specimens of ANSP 128695 result from having been introduced from the aquarium trade. It is unknown if this population is extant.

\section{Lasiancistrus heteracanthus (Günther, 1869) \\ Fig. 6}

Chaetostomus heteracanthus Günther, 1869:425. Upper Amazon, Peru.

Material Examined: Ecuador, Napo: FMNH 111719, 1, 108.3 $\mathrm{mm}$ SL, río San Miguel- río Putumayo- río Amazonas drainage, río San Miguel, río Conejo at bridge on road from Lago

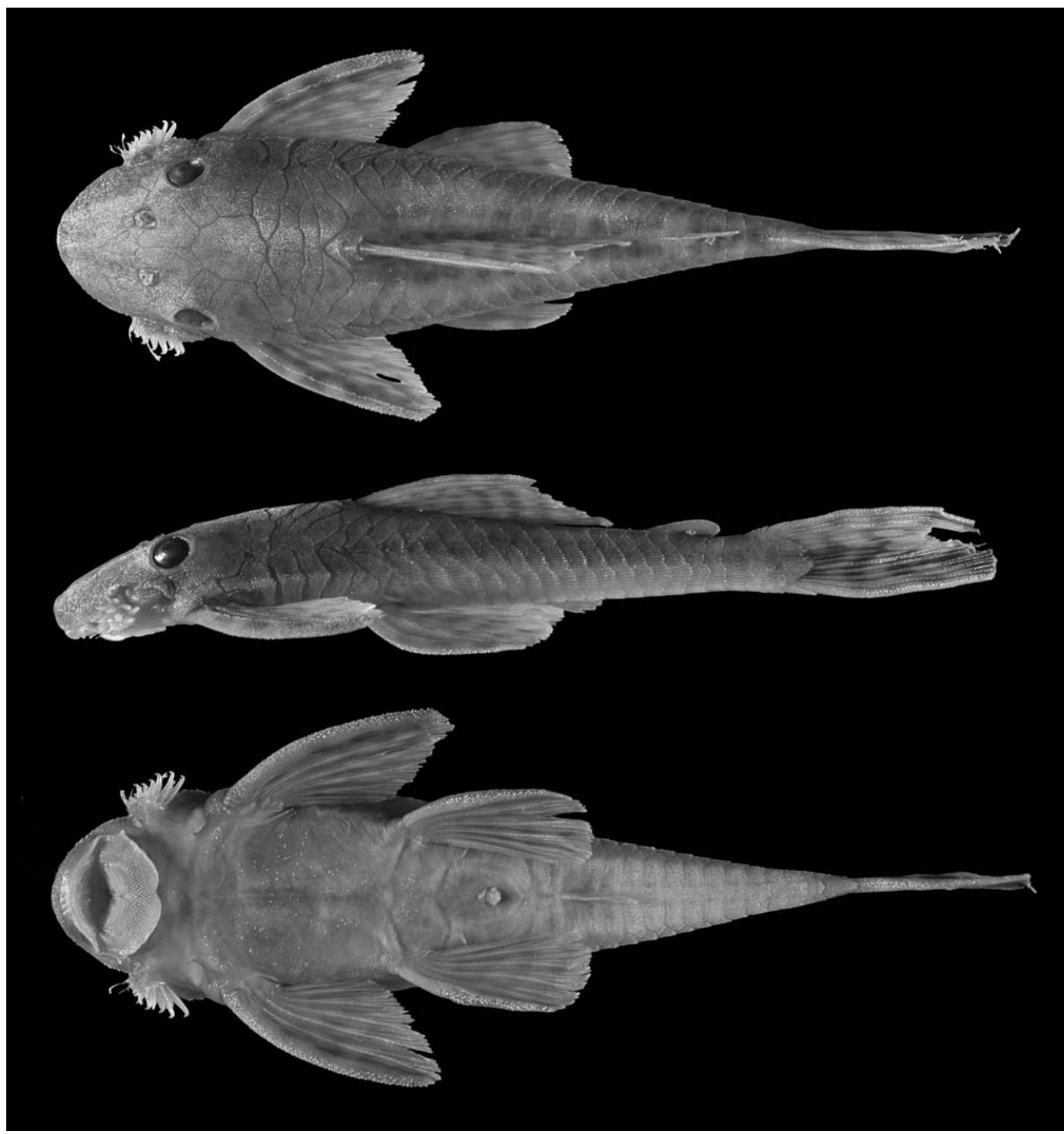

Fig. 6. Dorsal, lateral, and ventral views of Lasiancistrus heteracanthus, FMNH 111719, 108.3 mm SL. 
Agris to Lumbaqui, near Santa Cecilia, 0³'30"N, 77²'0"W, 17 Sep 1983. Peru, no department given: BMNH 1869.5.21.3, 1, $149.2 \mathrm{~mm}$ SL, holotype, upper Amazon, Bartlett. Loreto: SIUC 27970, 1, 66.2 mm SL, río Amazonas drainage, río Napo at Mazan, 347.48’S, 73¹4.90’ W, 19 Jul 1995.

Diagnosis. Lasiancistrus heteracanthus can be separated from L. caucanus, L. saetiger, and L. tentaculatus by having abdominal plates (vs. abdominal plates absent), from $L$. schomburgkii and L. saetiger by having dark spots in the dorsal and caudal fins ( $v s$. white spots or all dark), and from $L$. guacharote by not having the abdominal plates restricted to a region near the insertion of the pectoral-fin spine.

Description. See genus description for more information. Morphometrics in Table 2. Largest specimen 149.2 mm SL. Abdomen with small platelets anteriorly. 23-25 (mode $=24)$ plates in median series. 10-19 whiskerlike odontodes in evertible cheek mass $(\mathrm{N}=3) ; 24-32(\mathrm{~N}=3)$ total hypertrophied odontodes in cheek mass.

Color. Large, light spots barely visible on brown head, becoming mottling on dorsal and lateral surfaces of body. Distinct, midlateral stripe in larger specimen with more diffuse stripe located down middle of dorsal plates, both stripes beginning at vertical through dorsal-fin spine. Small spots present along dorsal spine and rays, spots not extending onto membrane. Medium spots on paired-fin rays and spines combining to form bands, but spots lighter on membranes. Lower lobe of caudal darker than upper lobe. Large spots on lower lobe of caudal combining to form bands that angle anteroventrally in upper half of lower lobe and posteroventrally in lower half. Small spots only on rays of upper caudal lobe, spots not connected to form bands, but if bands were formed, they would be angled posteroventrally. Abdomen slightly lighter tan than sides. Color of larger recently collected specimen (FMNH 111719) more intense than that of smaller specimen (SIUC 27970) collected from muddy waters of lower río Napo (pers. obs.). Color of holotype gone except for some faint, dark spots in dorsal and caudal fins.

Sexual dimorphism. No sexual dimorphism observed; specimens might not be mature. The holotype appears to be developing whiskerlike odontodes on the snout.

Range. The type locality of Lasiancistrus heteracanthus is stated as the upper Amazon of Peru. Only two specimens are available with good localities (FMNH 111719 and SIUC 27970) from the upper río Napo of Ecuador and the lower río Napo of Peru (Fig. 3).

Comments: Lasiancistrus heteracanthus appears to be very rare, and only three specimens were examined. The type of $L$. heteracanthus has the color almost absent; however, some faint, dark spots are visible on the dorsal and caudal fins. The only specimens examined from the Amazon drainage that have dark spots are FMNH 111719 and SIUC 27970, and these two specimens were used for the color description.

\section{Lasiancistrus saetiger, new species}

Fig. 7

Holotype. MCP 37942, 100.1 mm SL, BRAZIL, Pará, rio Guamá near Ourém, $1^{\circ} 34^{\prime} 07^{\prime} \mathrm{S}, 47^{\circ} 10^{\prime} 08^{\prime \prime} \mathrm{W}$ (purchased from an aquarium dealer and the coordinates are for his house on the edge of the river).

Paratypes. MCP 22017, 2, 81.2-85.0 mm SL, and AUM 42757, 1, $77.2 \mathrm{~mm} \mathrm{SL}$, same data as holotype.

Diagnosis. Lasiancistrus saetiger can be separated from $L$ heteracanthus and L. guacharote by having no plates on the abdomen, from L. schomburgkii by having large white spots on the head (vs. small white spots), by having the plates of the body outlined in black ( $v s$. entire body uniformly dark), and by having no spots in the dorsal and caudal fins ( $v s$. usually with small white spots), and from L. tentaculatus by having whiskers on the snout of nuptial males ( vs. tentacules longer than their associated odontodes), and from L. caucanus and L. tentaculatus by lacking dark spots in the dorsal and caudal fins ( $v s$. with dark spots).

Description. Morphometrics in Table 2. Largest specimen $100.1 \mathrm{~mm}$ SL. Body strongly dorsoventrally compressed and moderately wide. Head and nape gently sloped to insertion of dorsal fin. Dorsal profile very slightly sloped ventrally to dorsal procurrent caudal-fin spines, then rising slightly to caudal fin. Ventral profile flat to caudal fin. Supraorbital ridge almost absent with interorbital space slightly concave, almost flat. Supraorbital ridge continues as slightly higher, rounded ridge from anterior of orbit to slightly anteroventral of anterior nare. Mesethmoid raised slightly above lateral surface of snout to form slight ridge. Head contours smooth. Eyes small to medium.

Keels absent. All plates slightly convex medially to produce cylindrical body. Mid-dorsal and mid-ventral plate rows incomplete, generally ending below adipose fin; three rows of plates on caudal peduncle. Abdomen naked. First anal-fin pterygiophore not exposed to form platelike structure. 24 plates in median series.

Frontals, infraorbitals, nasals, opercles, pterotics, sphenotics, and supraoccipital supporting odontodes. Opercular odontodes occasionally moderately hypertrophied, thick, and sharp; whiskerlike odontodes rarely present on opercle. Whiskerlike odontodes present in evertible cheek mass and occasionally at anterolateral corner of snout; 7-15 whiskerlike odontodes in evertible cheek mass $(\mathrm{N}=4) ; 30-39$ $(\mathrm{N}=4)$ total hypertrophied odontodes in cheek mass. Cheek plates evertible to approximately $90^{\circ}$ from head, hypertrophied cheek odontodes folded under opercle when relaxed. Odontodes on tip of pectoral-fin spine slightly hypertrophied. Odontodes on lateral plates not enlarged to form keels. 
Dorsal fin not reaching preadipose plate when adpressed; dorsal-fin spine not elongate, edge of dorsal fin straight. Dorsal-fin spinelet V-shaped, dorsal-fin spine lock functional. Dorsal fin II,7. Adipose fin with one preadipose plate and moderately long spine. Caudal fin slightly emarginate to forked, lower lobe longer than upper, i,14,i, with four dorsal procurrent caudal-fin rays and four ventral procurrent cau- dal-fin rays. Anal fin short with unbranched ray weak and usually about three quarters length of first branched ray. Anal fin i,5, Pectoral-fin spine reaching slightly posterior to insertion of pelvic fin when adpressed ventral to pelvic fin. Pectoral fin I,6. Pelvic fin reaching to posterior of anal-fin when adpressed. Pelvic fin i,5.

Dorsal flap of iris present. Flap between anterior and pos-

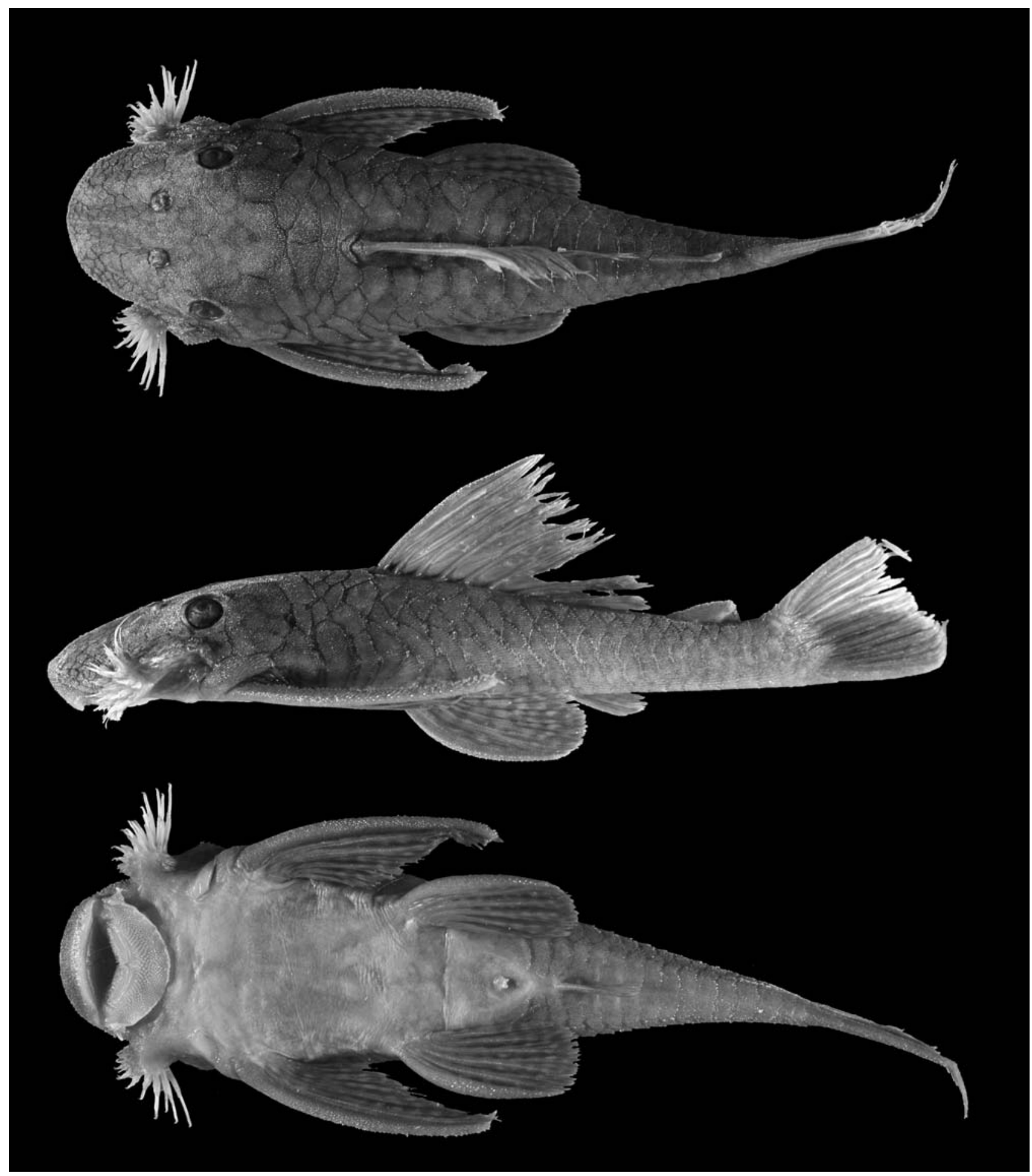

Fig. 7. Dorsal, lateral, and ventral views of holotype of Lasiancistrus saetiger, MCP 37942, $100.1 \mathrm{~mm}$ SL. 
terior nares short. Lips wide, fairly thin. Upper lip with small, round papillae. Lower lip with medium-sized papillae anteriorly and smaller ones posteriorly. Maxillary barbels very short, not reaching behind lower lip, occasionally completely adnate. Buccal papilla small. Jaws moderately wide, dentaries forming very oblique angle; premaxillaries forming a very shallow arc with an overall angle just slightly less than $180^{\circ}$. Teeth with fairly long, narrow cusps; lateral cusp approximately halflength of medial cusp, stalks of teeth long; 52-73 dentary teeth $(\mathrm{N}=4)$ and 61-67 premaxillary teeth $(\mathrm{N}=4)$.

Color. Body gray-brown with lighter spots. Medium-sized light spots on tip of snout, becoming very large posteriorly on head. Plates of nape and anterior body light gray-brown with dark edging giving appearance of large, light spots. Posteriorly on body, dark edges of plates most intense on anterior and posterior margins of plates forming oblique bars. Median fins without spots. Lower lobe of caudal darker than upper. Paired fins with medium-sized, round, light spots centered on rays. Pectoral-fin spines without spots; pelvic-fin spines with spots posteriorly, often faded. Abdomen slightly lighter than sides, with small, light spots laterally between posterior pectoral-fin insertion and insertion of pelvic-fin spine. Lower lobe of caudal fin darker than upper lobe.

Sexual dimorphism. No sexual dimorphism observed; specimens might not be mature.

Range. Lasiancistrus saetiger is known from a single collection of fishes from the rio Guamá, a tributary of the rio Capim, a drainage that enters the Atlantic just southeast of the mouth of the Amazon (Fig. 3).

Etymology. From the Latin saetiger meaning bristle bearing, in reference to the presence of whiskerlike odontodes in Lasiancistrus.

\section{Lasiancistrus schomburgkii (Günther, 1864)} Fig. 8

Chaetostomus schomburgkii Günther, 1864: 245. Guyana (likely Takutu, River drainage).

Hypostomus pictus Castelnau, 1855: 44 Pl. 22 (Fig. 2). Río Ucayali, Peru.

Hemiancistrus castelnaui Miranda-Ribeiro, 1911:58. Río Ucayali, Peru.

Ancistrus multispinis Holly, 1929:119-120. Mercado Blèin, Brazil (likely the Belem, Brazil market, see comments).

Hemiancistrus caquetae Fowler, 1945:115, Figs 17-20. Morelia, río Caquetá drainage, Colombia.

Lasiancistrus scolymus Nijssen \& Isbrücker, 1985: 242, Figs. 1-3. Rio Aripuanã, Humboldt, $10^{\circ} 10^{\prime} \mathrm{S}, 59^{\circ} 27^{\prime} \mathrm{W}$, rio Madeira system, Mato Grosso do Sul, Brazil.

Lasiancistrus guapore Knaack, 2000: 57, Fig. (unnumbered). $15^{\circ} 07.627^{\prime} \mathrm{S}, 58^{\circ} 57.786^{\prime} \mathrm{W}$, Mato Grosso, Brazil.
Material Examined. Brazil. Acre: MCP 28825, 3, 73.4-99.4 mm SL, rio Purus drainage, Igarapé Antimari, on highway BR 364, 58 km SE of Sena Madureira, 9²9'27"S, 68²1'20"W, 8 Aug 2001. MCP 28831, 5, 85.1-109.8 mm SL, rio Purus drainage, Igarapé Cassipian, on highway BR $364,38 \mathrm{~km}$ SE of Sena Madureira (tributary of rio Antimari), $9^{\circ} 16^{\prime} 42^{\prime \prime} \mathrm{S}, 68^{\circ} 29^{\prime} 44^{\prime \prime} \mathrm{W}, 8$ Aug 2001. Mato Grosso, rio Madeira drainage: MCP 28678, 1, $121.1 \mathrm{~mm}$ SL, holotype of L. guapore, rio Guaporé at Pontes e Lacerda, approx. 1507'S, 5857"W, 27 Sep 1998. MCP 28679, 7, 77.8-125.7 mm SL, paratypes of L. guapore, same data as MCP 28678. MZUSP 26809, 1, 141.7 mm SL, holotype of L. scolymus, rio Aripuanã, Humboldt, 16 Oct 1986. Pará, rio Amazonas drainage: MZUSP 24167, 0, Lagoon close to the channel of Capitariquara, near Jatobal, rio Tocantins, 18 Nov 1970. MZUSP 34152, 2, 91.3-101.4 mm SL and MZUSP 34153, 1, $106.3 \mathrm{~mm} \mathrm{SL}$, rio Itacaiunas, serra dos Carajas, Caldeirão, Jun-Jul 1983. MZUSP 34154, 1, 110.7 mm SL, rio Itacaiunas, Caldeirão, cachoeira Carreira Comprida, serra dos Carajas, Nov 1983. MZUSP 34155, 3, 104.0-124.7 mm SL, rio Itacaiunas, Caldeirão, Apr-May 1983. MZUSP 41681, 0, Igarapé do 11, km 11 on the Tucuruí-Mato Grosso road, 22 Nov 1970. MZUSP 43256, 5, 91.0-107.8 mm SL, rio Tocantins drainage, rio Itacaiunas, Caldeirão, Cachoeira Carreira Comprida, Serra dos Carajás, approx. $5^{\circ} 52^{\prime} \mathrm{S}, 50^{\circ} 32^{\prime \prime} \mathrm{W}, 14$ Oct 1983. Rondônia: MCP 35643, 4, 41.9-58.1 $\mathrm{mm} \mathrm{SL}$, small river (tributary of the rio Comemoração), rio Madeira drainage, on highway BR-364 near Vilhena and Pimenta Bueno, 12²6’30"S, 060³3'50"W, 14 Jul 2004. MCP 35645, 5, 54.0-61.4 mm SL, rio Madeira drainage, Igarapé do Miolo, circa $15 \mathrm{~km}$ NW of Ji-Paraná, on highway BR-364, $10^{\circ} 47^{\prime} 30$ "S, $062^{\circ} 02^{\prime} 23 " \mathrm{~W}, 16$ Jul 2004. MCP 35653, 6, 80.8-103.5 $\mathrm{mm}$ SL, narrow river near Jaru, circa $66 \mathrm{~km}$ from Ji-Paraná on highway BR-364, rio Madeira drainage, 10³2’24"S, 062 23’36"W, 16 Jul 2004. MNRJ 15710, 2, 101.8-120.2 mm SL, rio Machado drainage, Ouro Preto do Oeste, rio Urupá, 13 Jul 1986. MNRJ 15731, 1, $60.5 \mathrm{~mm}$ SL, rio Boa Fonte-rio Jaru drainage, Ouro Preto do Oeste, rio São Domingo, 12 Jul 1986. Colombia. ANSP 71708, holotype of L. caquetae, Morelia, río Caquetá drainage, K. von Sneidern-Colombian Zoological Survey, 1945. Ecuador. State not given: USNM 163921, 2, 83.6-125.6 mm SL, río Bobonaza, tributary to upper Pastaza, Chichirota, 2²2'S, 76³8"W, Jan 1949. Napo, río Napo drainage: FMNH 111699, 1, $100.2 \mathrm{~mm}$ SL, rio Coca, downstream from rio Sardinas confluence, $00^{\circ} 06^{\prime} 00^{\prime \prime} \mathrm{S}$, 77²'30"W, 28 Sep 1981. FMNH 111702, 1, 70.0 mm SL, rio Napo at Pompeya (night), N shore and tower end of a sandy island in center of river, $0^{\circ} 26^{\prime} 30^{\prime \prime S}, 7^{\circ} 38^{\prime} 12^{\prime \prime} \mathrm{W}, 7$ Oct 1981. FMNH $111705,1,87.6 \mathrm{~mm} \mathrm{SL}$, rio Blanco, first tributary to rio Tiputini upstream from bridge (N side), $0^{\circ} 44^{\prime} 30^{\prime \prime} \mathrm{S}, 7^{\circ} 53^{\prime} 00^{\prime \prime} \mathrm{W}, 4$ Nov 1981. FMNH 111706, 2, 65.7-66.4 mm SL, rio Tiputini, rio Rumiyacu at bridge, $0^{\circ} 40^{\prime} 0^{\prime \prime S}, 76^{\circ} 53^{\prime} 42^{\prime \prime} \mathrm{W}, 4$ Nov 1981. FMNH $111707,1,110.4 \mathrm{~mm} \mathrm{SL}$, rio Napo at Puerto Misahualli, 1²’30"S, 77³9'12"W, 7 Nov 1981. FMNH 111710, 1, 101.4 mm SL, rio Anzu near El Capricho, 1¹1'48"S, 7752’42"W, 15 Nov 1981. FMNH 111711, 1, $87.7 \mathrm{~mm}$ SL, rio Jatunyacu at Puerto Napo, just below bridge (on north shore), 1 ${ }^{\circ} 3^{\prime} 30^{\prime \prime S}, 7^{\circ} 47^{\prime} 42^{\prime \prime} \mathrm{W}, 16$ Nov 1981. FMNH 111713, 1, $77.3 \mathrm{~mm}$ SL, rio Aguarico, rio Teteye, 4.7 $\mathrm{km} \mathrm{N}$ of Lago Agrio at bridge on road to El Conejo and upstream for ca.100m, $0^{\circ} 7^{\prime} 42^{\prime \prime N}, 76^{\circ} 52^{\prime} 42^{\prime \prime} \mathrm{W}, 18$ Sep 1983. FMNH 111717, 3, 69.1-124.0 mm SL, rio Shushufindi, lower reaches (about $2 \mathrm{~km}$ upstream from mouth in rio Aguarico) (rio Aguarico drainage), $0^{\circ} 17^{\prime} 30^{\prime \prime} \mathrm{S}, 76^{\circ} 25^{\prime} 36^{\prime \prime} \mathrm{W}, 24$ Nov 1983. FMNH 111718, 2, 68.5117.8, Quebrada Apoalla, tributary to lower rio Shushufindi, $0^{\circ} 17^{\prime} 0^{\prime \prime S}, 76^{\circ} 27^{\prime} 0 " \mathrm{~W}, 24$ Nov 1983. Pastaza, río Cusuimi drainage: 
FMNH 70862, 11, 1 c\&s, 65.7-77.4 mm SL and FMNH 97333, 1, $71.1 \mathrm{~mm}$ SL, on río Cusuimi about $150 \mathrm{~km} \mathrm{SE}$ of Puyo, $18 \mathrm{Jul} 1971$. Guyana. State unknown: BMNH 1845.3.5.26-27, 2 (not measured), syntypes of $L$. schomburgkii, no precise locality. Rupununi (Region 9): AUM 35532, 2, 34.2-54.7 mm SL, Essequibo River drainage, Rupununi River at Karanambo. AUM 35541, 4, 61.3-87.3 mm SL, Takutu River drainage, Yuora River, tributary of the Ireng River, $6.7 \mathrm{~km}$ NE Karasabai. Peru. State not given: FMNH 84105, 1, $161.7 \mathrm{~mm}$ SL, Mouth of rio San Alejandro at junction with Sungaro Yacu, 1 Aug 1975. FMNH 84113, 1, 93.3 mm SL, rio San Alejandro, 2 Aug 1975. FMNH 84301, 1, 133.2 mm SL, rio Pachitea Expedi- tion?. FMNH 95965, 1, 86.7 mm SL, Peru, 1975. MNHN A-9573, 1, $105.8 \mathrm{~mm}$ SL, holotype of L. pictus and L. castelnaui, río Ucayali, Castelnau. Amazonas: FMNH 97002, 1, 78.3 mm SL, río Marañon drainage, rio Marañon at and across from St. Maria de Nieva and confluence of rio Nieva with rio Marañon, 16 Apr 1980. Huallaga, río Ucayali - río Amazonas drainage: MUSM 12800, 0, Pachitea, Yuyapichis, creek $1.5 \mathrm{~km}$ from the mouth, $27 \mathrm{Jul} 1988$. Huanuco, río Pachitea-río Ucayali drainage: ROM 55780, 1, $51.3 \mathrm{~mm} \mathrm{SL}$, $1.5 \mathrm{~km}$ W of Panguana Station, Llullapichis River, 9³7'S, 745' 'W, 26 Jul 1988. ROM 55781, 1, 87.0 mm SL, Approximately $2 \mathrm{~km}$ upstream from mouth (at Pachitea River) Llullapichis

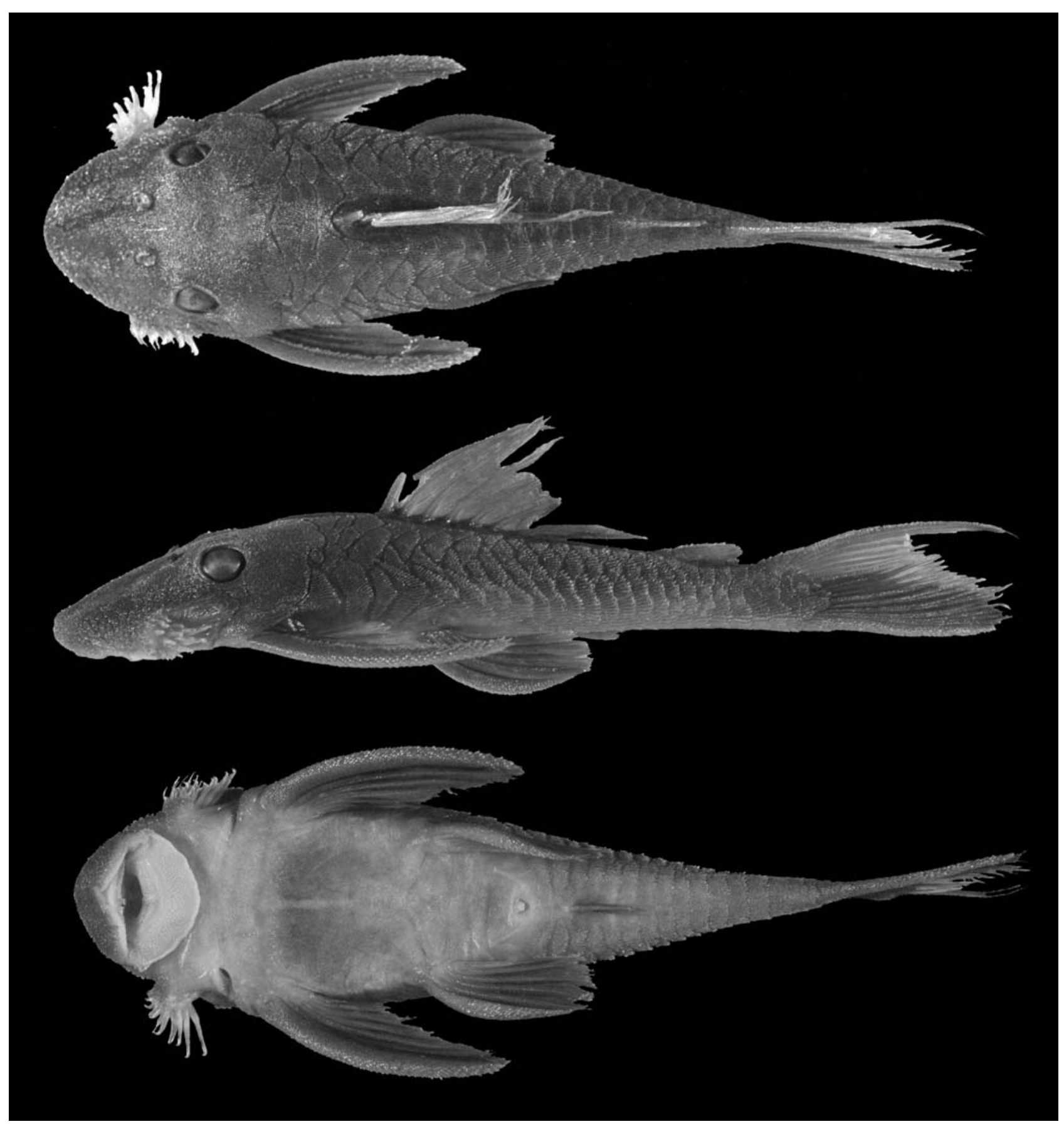

Fig. 8. Dorsal, lateral, and ventral views of Lasiancistrus schomburgkii, FMNH 111717, 124.0 mm SL. 
River, 9³7'S, 7457’W, 29 Jul 1988. Loreto: río Amazonas drainage: Rashaya, río Pisqui basin, Víbora caño, 17 May 1997. San Martin: río Amazonas drainage: MUSM 14313, 0, Moyabamba, río Mayo, 26 Dec 1998. Ucayali, río Ucayali - río Amazonas drainage: MUSM, Coronel Portillo, Pucallpa, río Aguaytia, río Neshuya, 1 river km below the Neshuya bridge, 15 Sep 1988. Venezuela. Amazonas, río Orinoco drainage: AUM 39224, 0, río Ventuari at mouth of caño Camoni, $145 \mathrm{~km}$ NNE of Macuruco, $189 \mathrm{~km} \mathrm{NE}$ of San Fernando de Atabapo, $05.05588^{\circ} \mathrm{N}$, 066.32742 ${ }^{\circ} \mathrm{W}, 8$ Apr 2004.

Diagnosis. Lasiancistrus schomburgkii can be separated from all other Lasiancistrus by having a dark body usually with small white spots (vs. large white spots; spots are occasionally absent in preserved L. schomburgkii, but no other Lasiancistrus will be entirely dark) and by having the dorsal fin either uniformly dark or with light spots (vs. with dark spots) and by lacking dark spots on any of the fins ( $v s$. dark spots present on dorsal, caudal, and paired fins in all except L. saetiger). Lasiancistrus schomburgkii can additionally be separated from L. saetiger by having the plates not outlined with dark pigment.

Description. See genus description for more information. Morphometrics in Table 3. Largest specimen 161.7 mm SL.
Abdomen ranging from having no plates, to just a few plates laterally under the pectoral girdle, to having much of the anterior two thirds of the abdomen with small plates (see Comments). 23-25 (mode $=24)$ plates in median series. 2-36 whiskerlike odontodes in evertible cheek mass $($ mode $=18, \mathrm{~N}$ $=61 ; 17-81($ mode $=21, \mathrm{~N}=61)$ total hypertrophied odontodes in cheek mass.

Color. Body and head dark brown to dark gray (almost black) with small to medium light spots. Abdomen light tan to gray, ventral surface of caudal peduncle slightly darker. Dorsal fin dark brown to gray with fin rays darker, usually with small white spots. Caudal fin with lower half dark, upper half sometimes very light, always lighter than lower half except along upper caudal-fin spine, sometimes very dark; caudal fin occasionally with small light spots on darkened lower lobe. Paired fins with small light spots centered on rays. Adipose and anal fins uniformly dark. Light spots much more intense and usually larger in living specimens, and may fade completely in preserved specimens.

Range. Lasiancistrus schomburgkii is found throughout much of the Amazon basin and the upper Orinoco and Essequibo River basins (Fig. 3).

Table 3. Selected morphometrics of Lasiancistrus schomburgkii and L. tentaculatus. Ratios are percent of SL (Predorsal L. to Pelvic-dorsal D.) or percent of Head L. (Head-eye L. to Premaxillary tooth cup L.).

\begin{tabular}{|c|c|c|c|c|c|c|c|c|c|}
\hline \multirow[b]{2}{*}{ Landmarks } & \multirow[b]{2}{*}{ Measurement } & \multicolumn{4}{|c|}{ L. schomburgkii } & \multicolumn{4}{|c|}{ L. tentaculatus } \\
\hline & & $\mathbf{N}$ & Mean & SD & Range & $\mathbf{N}$ & Mean & SD & Range \\
\hline $1-20$ & $\mathrm{SL}(\mathrm{mm})$ & 91 & 86.3 & 23.4 & $34.2-161.7$ & 69 & 63.2 & 19.3 & $33.5-147.6$ \\
\hline $1-10$ & Predorsal L. & 91 & 44.8 & 1.7 & $41.5-51.3$ & 69 & 44.9 & 1.9 & $40.9-50.3$ \\
\hline $1-7$ & Head L. & 90 & 36.6 & 1.4 & $33.3-41.3$ & 69 & 36.8 & 1.6 & $33.4-40.5$ \\
\hline $8-9$ & Cleithral W. & 91 & 29.8 & 2.1 & $25.9-35.8$ & 69 & 28.2 & 2.4 & $19.8-33.1$ \\
\hline $1-12$ & Head-pectoral L. & 91 & 28.2 & 1.7 & $24.9-32.1$ & 69 & 27.5 & 1.4 & $24.7-31.1$ \\
\hline $12-13$ & Thorax L. & 91 & 22.9 & 1.7 & $19.7-27.7$ & 69 & 22.4 & 2.2 & $17.5-28.5$ \\
\hline $12-29$ & Pectoral-spine L. & 89 & 32.0 & 3.4 & $24.6-40.7$ & 67 & 29.6 & 2.5 & $22.6-34.7$ \\
\hline $13-14$ & Abdominal L. & 91 & 22.2 & 1.2 & $19.3-25.6$ & 69 & 21.7 & 1.2 & $17.6-24.4$ \\
\hline $13-30$ & Pelvic-spine L. & 88 & 23.5 & 1.2 & $19.8-26.1$ & 69 & 23.9 & 1.7 & $19.6-27.8$ \\
\hline $14-15$ & Postanal L. & 91 & 32.7 & 2.3 & $24.8-37.2$ & 68 & 32.8 & 2.6 & $24.2-37.1$ \\
\hline $14-31$ & Anal-fin spine L. & 87 & 10.2 & 1.2 & $7.3-13.3$ & 68 & 11.7 & 2.1 & $8.0-19.5$ \\
\hline $10-12$ & Dorsal-pectoral D. & 91 & 27.3 & 1.5 & $22.5-32.5$ & 68 & 26.6 & 1.4 & $22.2-31.1$ \\
\hline $10-11$ & Dorsal spine L. & 70 & 26.4 & 2.0 & $21.4-30.2$ & 58 & 25.2 & 2.5 & $18.0-29.3$ \\
\hline $10-13$ & Dorsal-pelvic D. & 91 & 19.0 & 2.3 & $12.4-25.8$ & 69 & 16.7 & 2.3 & $10.3-22.6$ \\
\hline $10-16$ & Dorsal-fin base L. & 91 & 22.2 & 1.2 & $19.2-26.2$ & 69 & 20.5 & 1.9 & $14.4-25.9$ \\
\hline $16-17$ & Dorsal-adipose D. & 91 & 19.1 & 2 & $13.1-23.8$ & 69 & 19.8 & 1.8 & $15.3-24.1$ \\
\hline $17-18$ & Adipose-spine L. & 91 & 8.6 & 1.5 & $6.0-13.3$ & 66 & 7.9 & 1.6 & $4.0-11.0$ \\
\hline $17-19$ & Adipose-up. caudal D. & 91 & 13.9 & 1.9 & $9.9-18.6$ & 66 & 13.0 & 2.4 & $7.3-17.8$ \\
\hline $15-19$ & Caudal peduncle Dp. & 91 & 9.3 & 1.0 & $6.7-11.5$ & 65 & 9.2 & 1.0 & $6.1-11.6$ \\
\hline $15-17$ & Adipose-low. caudal D. & 91 & 19.0 & 1.5 & $14.4-22.7$ & 69 & 17.6 & 2.5 & $12.0-24.4$ \\
\hline $14-17$ & Adipose-anal D. & 91 & 19.4 & 1.4 & $15.7-22.0$ & 69 & 19.7 & 1.5 & $14.6-23.4$ \\
\hline $14-16$ & Dorsal-anal D. & 91 & 13.1 & 1.1 & $10.4-15.8$ & 69 & 12.4 & 1.7 & $8.7-19.4$ \\
\hline $13-16$ & Pelvic-dorsal D. & 91 & 23.3 & 1.9 & $19.0-27.4$ & 68 & 21.8 & 2.2 & $16.6-27.1$ \\
\hline $5-7$ & Head-eye L. & 90 & 39.0 & 2.2 & $32.3-43.4$ & 69 & 40.6 & 2.1 & $36.0-45.0$ \\
\hline $4-5$ & Orbit Dia. & 90 & 17.7 & 1.8 & $12.3-21.7$ & 69 & 17.8 & 1.8 & $12.5-22.6$ \\
\hline $1-4$ & Snout L. & 89 & 63.7 & 2.9 & $57.4-70.9$ & 69 & 60.9 & 3.3 & $52.0-67.1$ \\
\hline $2-3$ & Internares $\mathrm{W}$. & 88 & 15.2 & 1.3 & $12.8-18.5$ & 69 & 14.6 & 1.6 & $11.9-21.4$ \\
\hline $7-12$ & Head Dp. & 90 & 61.7 & 3.0 & $49.4-68.8$ & 69 & 59.4 & 3.5 & $44.9-73.9$ \\
\hline $1-24$ & Mouth L. & 90 & 45.5 & 3.1 & $37.8-53.0$ & 68 & 44.7 & 3.7 & $32.2-51.3$ \\
\hline $21-22$ & Mouth W. & 90 & 50.7 & 6.0 & $39.5-64.2$ & 69 & 47.3 & 5.1 & $37.2-60.9$ \\
\hline $22-23$ & Barbel L. & 89 & 4.2 & 1.1 & $1.8-7.3$ & 68 & 4.9 & 1.3 & $2.4-8.1$ \\
\hline $25-26$ & Dentary tooth cup L. & 90 & 16.2 & 3.1 & $10.9-24.4$ & 69 & 15.8 & 3.5 & $11.3-26.7$ \\
\hline $27-28$ & Premaxillary tooth cup L. & 90 & 15.9 & 3.1 & $10.5-22.5$ & 69 & 14.9 & 3.0 & $9.9-22.7$ \\
\hline
\end{tabular}


Comments. The types of Chaetostomus schomburgkii are in poor condition and are too small to have developed whiskerlike odontodes. The species was originally placed in Lasiancistrus by Isbrücker (1980), transferred to Guyanancistrus by Isbrücker et al. (2001), and later transferred to Pseudancistrus with the rest of Guyanancistrus (Armbruster, 2004). The poor condition of the smaller of the two syntypes is actually a good thing because it can be verified that the specimen has the two other synapomorphies for Lasiancistrus: three branchiostegals and an open dilatator operculi chamber can be observed in the smaller of the two syntypes. In addition, the specimens have three rows of plates on the caudal peduncle vs. four or five in Pseudancistrus.

Hemiancistrus castelnaui was described by Miranda Ribeiro (1911) as a replacement for Hypostomus pictus Castelnau, 1855 that was secondarily preoccupied in Hemiancistrus by Ancistrus pictus Kner, 1854 (now Dekeyseria picta). The color pattern of the holotype of $L$. castelnaui is mostly gone; however, there are a few small white spots in the dorsal fin, and I have examined only one species of Lasiancistrus from the upper Amazon of Peru (excluding the río Napo) making it most likely that the common species of the upper Amazon is L. schomburgkii.

Two species of Lasiancistrus have been described in the past 20 years, L. scolymus and L. guapore (Nijssen \& Isbrücker, 1985, Knaack, 2000). Lasiancistrus scolymus was based on a single individual and L. guapore was based on a single collection, and both species were described from the rio Madeira drainage of Brazil. Lasiancistrus scolymus was compared only to the holotype of $L$. heteracanthus and L. guapore only to the descriptions of $L$. scolymus and L. heteracanthus. Although some measurements were given as differences between the species in both descriptions, the results of the morphometric analysis in this study suggest that measurements cannot separate species of Lasiancistrus. The only other characteristic mentioned is the absence of plates on the abdomen in $L$. scolymus and the near absence of plates on the abdomen in L. guapore vs. a partially plated abdomen in $L$. heteracanthus. No comparisons were made with $L$. castelnaui or L. schomburgkii whose types are also without plates on the abdomen.

Specimens of Lasiancistrus schomburgkii from northern tributaries of the Madeira, tributaries of the Amazon upstream of the Madeira, and northern tributaries of the Amazon, the Orinoco, and the Essequibo tend to have many small, embedded plates on the abdomen, although the number of plates varies considerably, and plates are absent at least in the holotype of L. pictus. Two specimens from the río Ucayali basin (MUSM 14313) exhibit almost the entire range of variation in abdominal plating in L. schomburgkii. One specimen ( $92.6 \mathrm{~mm} \mathrm{SL}$ ) has a single plate medial to the insertion of the right pectoral-fin spine and two medial to the left pectoral-fin spine and none in the center of the body. The other specimen (91.1 mm SL) has many small plates below the pectoral girdle and a large patch in the center of the body behind the pectoral girdle. Specimens from southeastern tributaries of the Madeira and southern tributaries of the Amazon downstream of the Madeira have no plates on the abdomen. Specimens upstream of the rio Aripuanã (a southeastern tributary of the Madeira) are variable with specimens ranging from having no abdominal plates to a moderate amount. Based on the tree in Armbruster (2004), the absence of abdominal plates in Lasiancistrus is the plesiomorphic condition.

The type of Ancistrus multispinis is presumably lost (E. Mikschi, pers. comm..), and there is no information to confirm that the species is a Lasiancistrus. The type locality is stated as "Mercado Blèin" (Holly, 1929:120), which is likely to be the Belem market. The original description describes a $148 \mathrm{~mm}$ long fish with 39 hypertrophied odontodes on the cheek, plates on the edge of the snout, and no tentacles, which are consistent with Lasiancistrus (Holly, 1929), however, the specimen is described as having an anal-fin ray count of i,4 while most Lasiancistrus are i,5. A count of i,4 is rare in Lasiancistrus, but is occasionally present. The species could be considered incertae sedis in the Ancistrini; however, the description is consistent with a Lasiancistrus, and I prefer to leave it as a Lasiancistrus. Both the rio Tocantins and the rio Capim have their mouths near Belem making it possible that the species is either L. schomburgkii, which is from the Tocantins or the population described below as L. saetiger, which is described from the Capim. Holly (1929) describes the color as light brown with a darker back and brown fins. The specimens of $L$. saetiger are clearly spotted whereas $L$. schomburgkii is often entirely brown. Based on color, range, and that the description of the species is not inconsistent with $L$. schomburgkii, I am recognizing A. multispinis Holly as a synonym of $L$. schomburgkii.

The type of Lasiancistrus caquetae is very small (41.9 $\mathrm{mm} \mathrm{SL}$ ) and in poor condition. The specimen is entirely dark brown, seemingly the same as when it was described (Fowler, 1945). The only other described species that would likely be found the area where $L$. caquetae was collected are $L$. heteracanthus (which has dark spots on the fins) and $L$. schomburgkii. The original color description suggests that the species is not $L$. heteracanthus. Unfortunately, I have examined no other specimens from the Caquetá River; however, based on the original description of the lack of spots on the fins, it is most likely that $L$. caquetae is also a synonym of L. schomburgkii.

Some of the specimens examined from southern Amazonian tributaries have a couple of the teeth replaced by whiskerlike odontodes. Armbruster \& Page (1996) speculated that the elongate, unicuspid teeth of nuptial male Hypostomus ammophilus were the result of a pleiotropic affect of the elongation of the body odontodes in nuptial males. Thus, there may be some correlation between the development of the integumentary teeth and the oral teeth. This correlation may also explain why some of the teeth in Lasiancistrus schomburgkii may be replaced by whiskerlike odontodes. 


\section{Lasiancistrus tentaculatus, new species} Fig. 9

Holotype. MCNG 19744, 147.6 mm SL, río Las Marias, near El Portrero, below the metal bridge, $09^{\circ} 05^{\prime} \mathrm{N}, 69^{\circ} 39^{\prime} \mathrm{W}, \mathrm{D}$. C. Taphorn, A. Flecker, B. Feifarek, L. Van Balen, 12 Nov 1986. Paratypes. All collections Venezuela. Apure: INHS 28283, 44 (5 measured), 2 c\&s, 52.9-76.8 mm SL, tributary to río Suripa, $36 \mathrm{~km}$ NE La Pedrera on highway 5, L. M. Page, B. M. Burr, P. A. Ceas, C. A. Taylor \& S.R. Walsh, 6 Jan 1992. Carabobo, río Orinoco drainage: MCNG 15345, 1, 89.5 mm SL, caño Guamita, highway to los Naranjos, approximately $15 \mathrm{~km}$ from the crossroads, $10^{\circ} 02$ ' $50^{\prime \prime} \mathrm{N}, 067^{\circ} 54^{\prime} 30^{\prime \prime} \mathrm{W}$, D. Taphorn, S. Reid, \& C. Olds, 19 Oct 1986. Barinas, río Orinoco drainage: INHS 29866, 48 (1 measured), 6 c\&s, 77.0 mm SL, caño Yaure, Yaure on highway 5, $36 \mathrm{~km}$ NE La Pedrera, 742’05"N, 71¹7'77"W, L. M. Page, S. Huhndorf, \& J. L. Crane, 26 Jan 1993. Cojedes, río Orinoco drainage: INHS 28988, 2, 49.0-69.8 mm SL, río San Carlos WNW Las Vegas, 9³3’40"N, 68³8'89"W, J. W. Armbruster, D. C. Taphorn, L. M. Page, K. S. Cummings, C. A. Mayer, P. A. Ceas, C. A. Laird \& M.H. Sabaj, 9 Jan 1993. INHS 29062, 6 (2 measured), 58.3-79.3 mm SL, río Camoruco, about 10 km NW Libertad, D. C. Taphorn, L. M. Page, K. S. Cummings, C. A. Mayer, P. A. Ceas, J. W. Armbruster, C. A. Laird \& M. H. Sabaj, 9 Jan 1993. INHS 32030, 3 (1 measured), 67.3 mm SL, río San Carlos, $2 \mathrm{~km}$ W Las Vegas at caño Hondo, on rd. from Las Vegas to Libertad, 9³1'51"N, 68³9'39"W, J. W. Armbruster, M. H. Sabaj, K. S. Cummings \& C. A. Mayer, 14 Jan 1994. J. W. Armbruster, P. A. Ceas, M. Campos, R. Suarez \& J. A. Llerandi, 16 Jan 1995. Guarico, río Orinoco drainage: ANSP 163455, 1, $38.0 \mathrm{~mm}$ SL, Tributary of río Paya (tributary of río Guarico), 23 $\mathrm{km}$ S of San Juan de los Morros on Federal Highway 2, N. R. Foster, 29 Nov 1966. INHS 34617, 2, 59.6-68.9 mm SL, río San Jose, Parque Nacional Aguaro-Guariquito, 9²8'55"N, 6653'19"W, J. W. Armbruster, P. A. Ceas, M. Campos, R. Suarez \& J. A. Llerandi, 16 Jan 1995. Portuguesa, río Orinoco Drainage: AUM 17181, 2, 59.3-60.0 mm SL, caño Maraca, tributary of the caño Igues, Guanare-Guanarito road at road km 60, $8.8275^{\circ}$ N, 069.345W, J. W. Armbruster, M. Hardman, J. D. Evans, \& J. A. Thomas, 17 Dec 1999. AUM 27728, 3, 67.0-71.7 $\mathrm{mm}$ SL, caño Las Marias, tributary of the río Portuguesa, at town of Quebrada Seca, approximately $45 \mathrm{~min}$. upstream by car from Hwy. 5, 22 km NNW Guanare, J. W. Armbruster \& O. León, 28 Feb 1998. AUM 22663, 8 (4 measured), 52.1-94.4 mm SL, caño Mamón, tributary of río Portuguesa, in El Mamón, $24 \mathrm{~km} \mathrm{E}$ Guanare, $9.07167^{\circ} \mathrm{N}, 069.515^{\circ} \mathrm{W}$, J. W. Armbruster, M. Hardman, J. D. Evans, \& J. A. Thomas, 2 Jan 2000. AUM 22792, 3 (1 measured), $76.6 \mathrm{~mm}$ SL, río Portuguesa, at Hwy 5 bridge, $9.0818^{\circ} \mathrm{S}, 069.68159^{\circ} \mathrm{W}, \mathrm{J}$. W. Armbruster, M. Hardman, J. D. Evans, \& J. A. Thomas, 31 Dec 1999 - 1 Jan 2000. AUM 228334 (2 measured), 66.7-80.8 mm SL, same locality and collectors as AUM 17181, 1 Jan 2000. AUM 41708, 4 (0 measured), same locality as AUM 22792, M. H. Sabaj, D. C. Werneke, N. K. Lujan, L. S. de Souza, \& O. Leon, 29 Mar 2004. CU 82650, 1, 84.3 mm SL, río Las Marias, río Portuguesa drainage, $9.2000^{\circ} \mathrm{N}, 69.7000^{\circ} \mathrm{W}$, P. B. McIntyre et al., 31 Jan 2001.
INHS 28650, 1, $105.5 \mathrm{~mm}$ SL, río Portuguesa at Mata Larga, D. C. Taphorn, L. M. Page, K. S. Cummings, C. A. Mayer, P. A. Ceas, J. W. Armbruster, C. A. Laird \& M. H. Sabaj, 1 Jan 1993. MCZ 59382, 4 (2 measured), 57.4-67.0 mm SL, same locality as AUM 17181, D. C. Taphorn et al., 19 Mar 1983. UF 32331, 1, $76.5 \mathrm{~mm}$ SL, río Tucupido just behind the Santuarío de la Coromoto, ca $1.7 \mathrm{~km} \mathrm{SW}$ of Guanare, just above junction with río Guanare, D. C. Taphorn et al., 26 Mar 1981. UF 80706, 4, 41.1-63.7 mm SL, río Bocono in Puerto Paez, PortuguesaBarinas border, D. C. Taphorn, C. R. Gilbert, \& L. Nico, 10 Apr 1984. Trujillo, río Orinoco drainage: MCNG 27307, 4, 62.6-84.6 mm SL, río Carache, 27 Aug 1990.

Nontypes. Colombia. Meta, río Orinoco drainage: ANSP 128692 , 5, 41.0-58.3 mm SL, río Negro, downstream from main VillavicencioPuerto Lopez highway at La Balsa, W side of river, 29 Feb 1972. ANSP 131661, 0, río Negrito, downstream from bridge at La Balsa, río Meta drainage, 22 Mar 1975. UF 33421, 1, 51.0 mm SL, Guacavia River ENE of Villavicencio, 3 Jan 1973.Venezuela. Amazonas: AUM 39278, 0, río Parucito, río Ventuari Drainage, at raudales Salomon, $2.7 \mathrm{~km}$ NE of San Juan de Manapiare, $05.34637^{\circ} \mathrm{N}$, 066.03347 ${ }^{\circ} \mathrm{W}, 16$ Apr 2004. AUM 39849, 0, río Ventuari, beach below Raudales Tencua, $56 \mathrm{~km}$ ESE of San Juan de Manapiare, $05.04968^{\circ} \mathrm{N}, 065.62722^{\circ} \mathrm{W}, 19-20$ Apr 2004. MCNG 23846, 3, 38.5-43.7 $\mathrm{mm}$ SL, island in río Ocamo below Arata rapids, $03^{\circ} 05^{\prime} \mathrm{S}$, 64³7’W, 24 Jan 1990. MCNG 24246, 5, 28.7-55.8 mm SL, río Putaco near the confluence of the río Ocamo (river above ChicritaPora Rapids), 3 Feb 1990. MCNG 25802, 1, 33.5 mm SL, río Ocamo at Arata Rapids, $03^{\circ} 08^{\prime} \mathrm{N}, 6^{\circ} 34^{\prime} \mathrm{W}, 24$ Jan 1990. UF 77844, 2, 49.1-50.5 mm SL, río Ventuari at Tencua just below Tencua Falls, 20 Mar 1981. Apure, río Orinoco drainage: MCNG 21802, 1, 41.8 $\mathrm{mm} \mathrm{SL}$, río Cinaruco CORPOVEN camp, 06³1'50"N, $067^{\circ} 26^{\prime} 14^{\prime \prime W}, 20$ Apr 1989. Bolivar, río Caura drainage: MCNG 21596, 2, 43.4-64.4 mm SL, caño Icutú, two turns of the river below Icutú Falls, $05^{\circ} \mathrm{N}, 064^{\circ} \mathrm{W}, 13$ Mar 1989.

Diagnosis. Lasiancistrus tentaculatus is diagnosed by one unique autapomorphy, the presence of small tentacles (tentacules sensu Sabaj et al., 1999) on the snout of nuptial males that are larger than the supporting odontodes. All other Lasiancistrus whose nuptial males have been observed have whiskerlike odontodes at the anterolateral corners of the snout. In addition, L. tentaculatus can be separated from $L$ heteracanthus, L. guacharote, and some L. schomburgkii by having no plates on the abdomen, from L. schomburgkii and $L$. saetiger by having black spots in the dorsal, caudal, and paired fins fin (vs. no or white spots or entirely gray, respectively), and from $L$. caucanus by having a forked caudal fin (vs. emarginate).

Description. Morphometrics in Table 3. Largest specimen 147.6 mm SL. Morphometrics in Table 2. Largest specimen $100.1 \mathrm{~mm}$ SL. Body strongly dorsoventrally compressed and moderately wide. Head and nape gently sloped to insertion of dorsal fin. Dorsal profile very slightly sloped ventrally to dorsal procurrent caudal-fin spines, then rising slightly to caudal fin. Ventral profile flat to caudal fin. Supraorbital ridge almost absent with interorbital space slightly concave, almost flat. Supraorbital ridge continues as slightly higher, 


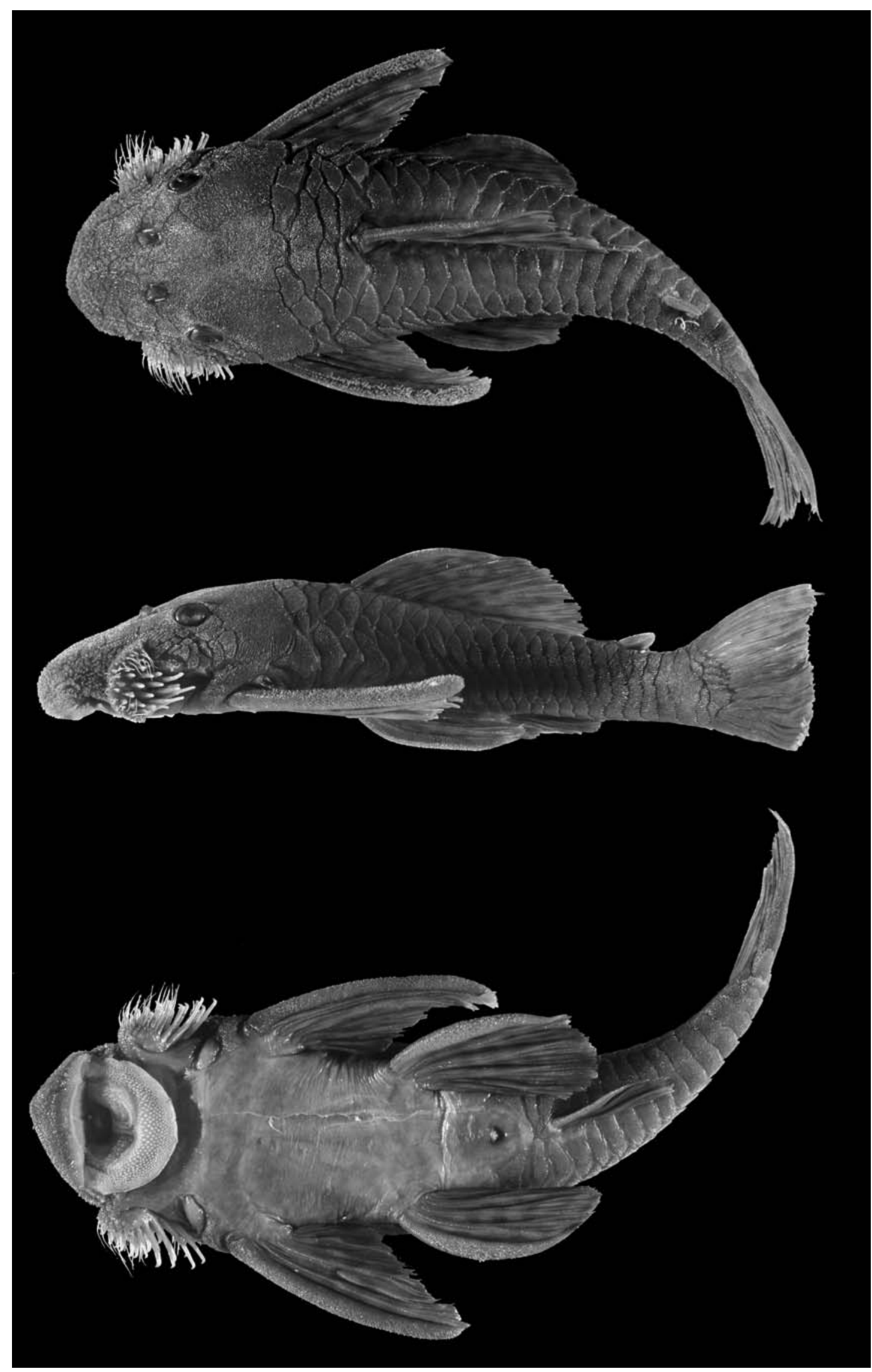

Fig. 9. Dorsal, lateral, and ventral views of holotype of Lasiancistrus tentaculatus, MCNG 19744, 147.6 mm SL. 
rounded ridge from anterior of orbit to slightly anteroventral of anterior nare. Mesethmoid raised slightly above lateral surface of snout to form slight ridge. Head contours smooth. Eyes small to medium.

Keels absent. All plates slightly convex medially to produce cylindrical body. Mid-dorsal and mid-ventral plate rows incomplete, generally ending below adipose fin; three rows of plates on caudal peduncle. Abdomen naked. First anal-fin pterygiophore not exposed to form platelike structure. 23-25 (mode $=24)$ plates in median series.

Frontals, infraorbitals, nasals, opercles, pterotics, sphenotics, and supraoccipital supporting odontodes. Opercular odontodes occasionally moderately hypertrophied, thick, and sharp; whiskerlike odontodes rarely present on opercle. Whiskerlike odontodes present in evertible cheek mass and occasionally at anterolateral corner of snout; 1-26 whiskerlike odontodes in evertible cheek mass (mode $=5, \mathrm{~N}=29) ; 12-60$ (mode $=36, \mathrm{~N}=31$ ) total hypertrophied odontodes in cheek mass. Cheek plates evertible to approximately $90^{\circ}$ from head, hypertrophied cheek odontodes folded under opercle when relaxed. Odontodes on tip of pectoral-fin spine slightly hypertrophied. Odontodes on lateral plates not enlarged to form keels.

Dorsal fin not reaching preadipose plate when adpressed; dorsal-fin spine not elongate, edge of dorsal fin straight. Dorsal-fin spinelet V-shaped, dorsal-fin spine lock functional. Dorsal fin II,7 (one of 76 I,6). Adipose fin with one preadipose plate and moderately long spine. Caudal fin slightly emarginate to forked, lower lobe longer than upper, i, 14,i (two of 60 i, 12,i), with four to five $($ mode $=$ five, $\mathrm{N}=26$ ) dorsal procurrent caudalfin rays and four to five (mode $=$ four, $\mathrm{N}=25$ ) ventral procurrent caudal-fin rays. Anal fin short with unbranched ray weak and usually about three quarters length of first branched ray. Anal fin i,5 (one of 76 i,4), Pectoral-fin spine reaching slightly posterior to insertion of pelvic fin when adpressed ventral to pelvic fin. Pectoral fin I,6 (one of 76 I,5). Pelvic fin reaching to posterior of anal-fin when adpressed. Pelvic fin i,5 $(\mathrm{N}=78)$.

Dorsal flap of iris present. Flap between anterior and posterior nares short. Lips wide, fairly thin. Upper lip with small, round papillae. Lower lip with medium-sized papillae anteriorly and smaller ones posteriorly. Maxillary barbels very short, not reaching behind lower lip, occasionally completely adnate. Buccal papilla small. Jaws moderately wide, dentaries forming very oblique angle; premaxillaries forming very shallow arc with an overall angle just slightly less than $180^{\circ}$. Teeth with fairly long, narrow cusps; lateral cusp approximately half-length of medial cusp, stalks of teeth long; 39-88 dentary teeth (mode = $74, \mathrm{~N}=23)$ and 29-89 premaxillary teeth $($ mode $=67, \mathrm{~N}=27)$.

Color. Body and head almost uniformly brown with slight mottling. Abdomen light tan, ventral surface of caudal peduncle slightly darker. Dorsal, caudal, and paired fins with dark spots centered on fin rays and that may form incomplete or wavy bands. Adipose and anal fins uniformly dark. Lower half of caudal fin generally darker than upper half.

Range. Lasiancistrus tentaculatus is found in the Orinoco
River basin of Colombia and Venezuela and in the lago Valencia drainage of Venezuela (Fig. 3).

Etymology. Derived from tentacule, the word used by Sabaj et al. (1999) to describe the small tentacles of Lasiancistrus, itself a diminutive of tentacle, which is derived from the modern Latin tentaculum meaning feeler and the Latin suffix -atus meaning provided with. Refers to the possession of tentacules along the snout in nuptial males of this species.

\section{Discussion}

Lasiancistrus nationi was described by Fernández-Yépez (1972) for specimens from the río Yaracuy of northern Venezuela. No Lasiancistrus are present from recent collections from this region at INHS and MCNG, and the photograph in Fernández-Yépez (1972) is of an Ancistrus as the snout is clearly lacking plates. Lasiancistrus nationi is therefore referred to as Ancistrus nationi (Fernández-Yépez, 1972), new combination.

Armbruster and Provenzano (2001) refer to an undescribed species they referred to as Lasiancistrus sp. from Amazonas, Venezuela. Although superficially similar to Lasiancistrus, it lacks whiskerlike odontodes, and no skeletons are available to confirm its identity. It further differs from L. tentaculatus by having light spots ( $v s$. dark spots) and from $L$. schomburgkii by lacking plates on the abdomen (all examined L. schomburgkii from Venezuela have plates) and by having spots (when present) that are greater than one half the diameter of the plates ( $v s$. less than one half). It is unknown what this species is at the current time, but it does not appear to be in Lasiancistrus.

Lasiancistrus guacharote, L. schomburgkii, and L. trinitatus were placed in Guyanancistrus by Isbrücker et al. (2001), and Guyanancistrus was placed in the synonymy of Pseudancistrus by Armbruster (2004). Lasiancistrus guacharote and L. schomburgkii are clearly members of Lasiancistrus. The description of L. trinitatus is poor; however, Günther (1864) states that it has four total anal-fin rays while Lasiancistrus almost always has six. There are no known specimens of Lasiancistrus or Pseudancistrus from Trinidad, and the only loricariids known from the island are Hypostomus robinii and a species of Ancistrus. Because there are no types of the species, the species should be listed as Chaetostomus trinitatus Günther, 1864, incertae sedis.

Contrary to the case presented by many other members of the Ancistrini being examined, the ranges of most of the species of Lasiancistrus are quite broad. The species with the greatest range is L. schomburgkii, which occupies most of the Amazon basin and the upper Orinoco and Essequibo basins as well. The species of Lasiancistrus are most commonly found in small creeks, typically in swift flow. However, some of the streams where Lasiancistrus can be found are in the lowlands, and hypoxia has been observed in one such stream (caño Maraca, río Portuguesa - río Orinoco drainage). This suggests that lowlands are not a barrier to the movement of the species. 
The biogeography of Lasiancistrus suggests that lowland fishes can fairly easily breach the barriers between the Orinoco and Essequibo and the Amazon. The range of $L$. schomburgkii is similar to Hypostomus hemicochliodon, which also makes it into the upper Orinoco (but not into the Essequibo). The two species have similar habitat preferences, occurring in the swift sections of otherwise lowland streams.

Also curiously within Lasiancistrus schomburgkii is that those populations with the presence of plates on the abdomen (likely the derived condition based on Armbruster 2004) are found in an arc that includes the northern Amazonian tributaries, the upper Orinoco and the Essequibo rivers while the plesiomorphic populations are from the southern Amazonian tributaries. Lasiancistrus are most common in lower piedmont streams. Due to the range of the plated and unplated populations of Lasiancistrus, it is likely that L. schomburgkii dispersed via stream capture events of these piedmont streams rather than crossing the lowlands and the Amazon.

The function of tentacules on the snouts of nuptial male Lasiancistrus tentaculatus and the pectoral fins of all Lasiancistrus and Ancistrus is unknown. Sabaj et al. (1999) speculated that the tentacles of Ancistrus are larval mimics that could potentially trick females into believing that males have larvae in the nest when they do not. Indeed, male Ancistrus are often found with larvae the size of their tentacles in their nests (see Sabaj et al., 1999 for review). Spawning in Lasiancistrus has not been reported, and members of Lasiancistrus are rarely found in the aquarium trade; however, it would be reasonable to speculate that the tentacules are mimicking a younger larva than the tentacles of Ancistrus. Although the larval mimicry hypothesis for Ancistrus and Lasiancistrus has not been tested, it is likely that the behavioral ecology of these species is quite interesting.

No morphometric, meristic, or skeletal differences could be found among the species of Lasiancistrus. The only differences between the species are the degree of abdominal plating (itself a characteristic that is likely to be very homoplastic) and coloration. The difficulty in using abdominal plating is underscored by $L$. schomburgkii, which has all of the observed character states for the genus. The only major difference between $L$. caucanus and $L$. guacharote is that $L$. caucanus has a naked abdomen and L. guacharote has a few small plates at the insertion of the pectoral-fin spine. Although this character was not useful in separating populations of $L$. schomburgkii, it was used to separate $L$. caucanus and $L$. guacharote because there was also geographic concordance.

The only major characteristic to be found other than color and abdominal plating between the species is the nuptial male condition of Lasiancistrus tentaculatus. Males of $L$. tentaculatus develop tentacules along the anterior margin of the snout while all other Lasiancistrus develop whiskerlike odontodes at the anterior corners of the snout. It is unknown how the tentacules or the whiskerlike odontodes are used. Presence of whiskerlike odontodes on the cheek does not appear to be sexually dimorphic, although males may have longer ones.

\section{Acknowledgements}

This project represents part of Planetary Biodiversity Inventory: All Catfish Species (Siluriformes) - Phase I of an Inventory of the Otophysi, a five year grant through the US National Science Foundation to describe all species of catfishes (NSF DEB-0315963). The project was also supported by NSF grant DEB-0107751. I am indebted to numerous people for help when visiting museums and for help in collecting specimens including: Mark Sabaj, John Lundberg, Mary Anne Rogers, Barry Chernoff, Phillip Willink, Mark Westneat, Richard Vari, Susan Jewett, Jeffrey Williams, Karsten Hartel, Lawrence Page, Robert Robins, David Werneke, Nathan Lujan, Lesley de Souza, Paul Pera, Justin Evans, Michael Hardman, Jackie Arjoon, Christopher Chin, Calvin Bernhard, Graham Watkins, Donald Taphorn, Roberto Reis, Luiz Malabarba, Pablo Lehmann, Paulo Buckup, Michael Retzer, Patrick Ceas, Christopher Laird, Kevin Cummings, Christine Mayer, Oscar León, Jeffrey Thomas, Brooks Burr, Jeffrey Stewart, Matt Thomas, Mario de Pinna, Oswaldo Oyakawa, John Friel, Hernan Ortega, and Erling Holm. Thanks to Marcelo Melo for translating the abstract to Portuguese.

\section{Literature Cited}

Armbruster, J. W. 1997. Phylogenetic relationships of the sucker-mouth armored catfishes (Loricariidae) with particular emphasis on the Ancistrinae, Hypostominae, and Neoplecostominae. Unpublished Ph.D. Dissertation, University of Illinois, Urbana-Champaign.

Armbruster, J. W. 2003. Peckoltia sabaji, a new species from the Guyana Shield (Siluriformes: Loricariidae). Zootaxa, 344: 1-12.

Armbruster, J. W. 2004. Phylogenetic relationships of the suckermouth armored catfishes (Loricariidae) with emphasis on the Hypostominae and the Ancistrinae. Zoological Journal of the Linnean Society, 141: 1-80.

Armbruster, J. W \& L. M. Page. 1996. Redesription of Aphanotorulus (Teleostei: Loricariidae) with description of one new species, A. ammophilus, from the Río Orinoco basin. Copeia, 1996(2): 379-389.

Armbruster, J. W \& F. R. Provenzano. 2000. Four new species of the suckermouth armored catfish genus Lasiancistrus (Loricariidae: Ancistrinae). Ichthyological Exploration of Freshwaters, 11(3): 241-254.

Cuvier, G. and A. Valenciennes. 1840. Histoire naturelle des poissons. Tome quinzième. Suite du livre dix-septième. Siluroïdes. 15: i-xxxi + 1-540.

Dahl, G. 1942. Three new fishes of the family Loricariidae from the Magdalena system. Kungliga Fysiografiska Sällskapets i Lund Förhandlingar, 11(8): 80-86.

Eigenmann, C. H. 1912. Some results from an ichthyological reconnaissance of Colombia, South America. Part I. (Contribution from the Zoölogical Laboratory of Indiana University, No. 127.). Indiana University Studies, 16: 1-27.

Fernández-Yépez, A. 1972. Análisis ictiológico del complejo 
hidrográfico (04) "Río Yaracuy". Direccion de Obras Hidraulicas, Ministerio de Obras Publicas, Republica de Venezuela. $25 \mathrm{p}$.

Fisch-Muller, S. 2003. Subfamily Ancistrinae. Pp. 373-400 In:

Reis, R. E., S. O. Kullander, \& C. J. Ferraris, Jr. (Eds.). Check list of the freshwater fishes of South and Central America, Edipucrs, Porto Alegre. $627 \mathrm{p}$.

Fowler, H. W. 1945. Colombian zoological survey. Pt. I. The freshwater fishes obtained in 1945. Proceedings of the Academy of Natural Sciences of Philadelphia, 97: 93-135.

Günther, A. 1864. Catalogue of the fishes in the British Museum. Vol. 5. Catalogue of the Physostomi, containing the families Siluridae, Characinidae, Haplochitonidae, Sternoptychidae, Scopelidae, Stomiatidae in the collection of the British Museum. Trustees, London, xxii + 455p.

Heitmans, W. R. B, H. Nijssen, \& I. J. H. Isbrücker. 1983. The mailed catfish genus Lasiancistrus Regan 1904, from French Guiana and Surinam, with descriptions of two new species (Pisces, Siluriformes, Loricariidae). Bijdragen tot de Dierkunde, 53(1): 33-48.

Holly, M. 1929. Einige neue Fischformen aus Brasilien. Anzeiger der Mathematisch-Naturwissenschaftlichen Classe der Kaiserlichen Akademie der Wissenschaften in Wien, 66: 117-120.

Isbrücker, I. J. H. 1980. Classification and catalogue of the mailed Loricariidae (Pisces, Siluriformes). Verslagen en Technische Gegevens, 22: 1-181.

Isbrücker, I. J. H. 2001. Nomenklator der Gattungen und Arten der Harnischwelse, Familie Loricariidae Rafinesque, 1815 (Teleostei, Ostariophysi). Datz Harnischwelse, 2: 25-32.

Isbrücker, I. J. H., I. Seidel, J. P. Michels, E. Schraml \& A. Werner. 2001. Diagnose vierzehn neuer Gattungen der Familie Loricariidae Rafinesque, 1815 (Teleostei, Ostariophysi). Datz Harnischwelse, 2: 17-24.

Knaack, J. 2000a. Ein weiterer neuer Harnischwels aus dem Rio Guaporé: Lasiancistrus guapore n. sp. Aquaristik Aktuell, 2000(9-10): 56-61.

Kner, R. 1854. Die Hypostomiden. Zweite Hauptgruppe der Familie der Panzerfische. (Loricata vel Goniodontes). Denkschriften Akademie der Wissenschaften in Wien, 7: 251-286
Leviton, A. E., R. H. Gibbs Jr., E. Heal, \& H. E. Dawson. 1985. Standards in herpetology and ichthyology: Part I. Standard symbolic codes for institutional resource collections in herpetology and ichthyology. Copeia, 1985(3): 802-832. Miranda Ribeiro, A. 1911. Fauna brasiliense. Peixes. Tomo IV (A) [Eleutherobranchios Aspirophoros]. Arquivos do Museu Nacional, 16: 1-504.

Nijssen, H. \& I. J. H. Isbrücker. 1985. Lasiancistrus scolymus, a new species of mailed catfish from Rio Aripuanã, Est. Mato Grosso do Sul, Brazil (Pisces, Siluriformes, Loricariidae). Bijdragen tot de Dierkunde, 55: 242-248.

Pietsch, T. W. (ed.). 1995. Historical portrait of the progress of ichthyology, from its origins to our own time by Georges Cuvier. A.J. Simpson (translator). John Hopkins Univ. Press, Baltimore. $366 \mathrm{p}$.

Regan, C. T. 1904. A monograph of the fishes of the family Loricariidae. Transactions of the Zoological Society of London, 17(1): 191-350.

Sabaj, M. H., J. W. Armbruster \& L. M. Page. 1999. Spawning in Ancistrus with comments on the evolution of snout tentacles as a novel reproductive strategy: larval mimicry. Ichthyological Exploration of Freshwaters, 10(3): 217-229.

Schaefer, S. A. 1986. Historical biology of the loricariid catfishes: phylogenetics and functional morphology. Unpublished Ph. D. Dissertation, The University of Chicago, Chicago.

Schaefer, S. A. 1997. The neotropical cascudinhos: systematics and biogeography of the Otocinclus catfishes (Siluriformes: Loricariidae). Proceedings of the Academy of Natural Sciences of Philadelphia, 148: 1-120.

Schultz, L. P. 1944. The catfishes of Venezuela, with descriptions of thirty-eight new forms. Proceedings of the United States National Museum, 94(3172): 173-338.

Received July 2005 Accepted November 2005 